\title{
The ubiquitous gp63-like metalloprotease from lower trypanosomatids: in the search for a function
}

\author{
ANDRÉ L.S. SANTOS ${ }^{1}$, MARTA H. BRANQUINHA ${ }^{2}$ and CLAUDIA M. D'AVILA-LEVY ${ }^{2}$ \\ ${ }^{1}$ Laboratório de Estudos Integrados em Bioquímica Microbiana, Departamento de Microbiologia Geral \\ Instituto de Microbiologia Prof. Paulo de Góes (IMPPG), Centro de Ciências da Saúde (CCS) \\ Universidade Federal do Rio de Janeiro (UFRJ), Bloco I, Ilha do Fundão \\ 21941-590 Rio de Janeiro, RJ, Brasil \\ ${ }^{2}$ Laboratório de Bioquímica de Proteases, Departamento de Microbiologia Geral \\ Instituto de Microbiologia Prof. Paulo de Góes (IMPPG), Centro de Ciências da Saúde (CCS) \\ Universidade Federal do Rio de Janeiro (UFRJ), Bloco I, Ilha do Fundão \\ 21941-590 Rio de Janeiro, RJ, Brasil \\ Manuscript received on October 31, 2005; accepted for publication on February 15, 2006; \\ presented by LUCIA MENDONÇA PREVIATO
}

\begin{abstract}
Plant and insect trypanosomatids constitute the "lower trypanosomatids", which have been used routinely as laboratory models for biochemical and molecular studies because they are easily cultured under axenic conditions, and they contain homologues of virulence factors from the classic human trypanosomatid pathogens. Among the molecular factors that contribute to Leishmania spp. virulence and pathogenesis, the major surface protease, alternatively called MSP, PSP, leishmanolysin, EC 3.4.24.36 and gp63, is the most abundant surface protein of leishmania promastigotes. A myriad of functions have been described for the gp63 from Leishmania spp. when the metacyclic promastigote is inside the mammalian host. However, less is known about the functions performed by this molecule in the invertebrate vector. Intriguingly, gp63 is predominantly expressed in the insect stage of Leishmania, and in all insect and plant trypanosomatids examined so far. The gp63 homologues found in lower trypanosomatids seem to play essential roles in the nutrition as well as in the interaction with the insect epithelial cells. Since excellent reviews were produced in the last decade regarding the roles played by proteases in the vertebrate hosts, we focused in the recent developments in our understanding of the biochemistry and cell biology of gp63-like proteins in lower trypanosomatids.
\end{abstract}

Key words: Trypanosomatidae, lower trypanosomatids, gp63, invertebrate host, adhesion, nutrition, protease.

\section{THE TRYPANOSOMATIDAE FAMILY}

The Trypanosomatidae family of the order Kinetoplastida is a cosmopolitan group of flagellates containing prominent groups that parasitize virtually every major group of eukaryotic organisms including animals, plants and other protists (Wal-

Correspondence to: A.L.S. Santos

E-mail: andre@micro.ufrj.br lace 1966, McGhee and Cosgrove 1980, Vickerman 1994). Trypanosomatids are distinguishable from other protozoa by distinctive organizational features such as the presence of kinetoplast DNA, a different type of mitochondrial DNA consisting of maxi- and mini-circle DNAs located in the single mitochondrion near the basal body of the flagellum; isolation of glycolytic enzymes in a special organelle, the gly- 
cosome; use of the flagellar pocket for molecular traffic into and out of the cell; and a unique method of generating cortical microtubules. In addition, these organisms exhibit unusual molecular phenomena such as antigenic variation, trans-splicing, RNA editing and peculiar nuclear organization. The trypanosomatids seem to be able to adapt with ease their energy metabolism to the availability of substrates and oxygen, and this may give them the ability to institute new life cycles if host behavior patterns allow (McGhee and Cosgrove 1980, Vickerman 1994).

Despite the great advances in combating infectious diseases over the past century, protozoan parasites continue to inflict a tremendous social and economic burden on human societies, particularly in tropical and subtropical regions of the world. In addition to being fascinating in its own right, the study of protozoan parasite biology may lead to important practical developments such as novel chemotherapeutic agents and vaccines (McGhee and Cosgrove 1980, Vickerman 1994). During their long evolutionary history, the Trypanosomatidae family has developed an impressive variety of life styles and adaptations to parasitism that comprises both monoxenous (involving a single host, usually an invertebrate) and heteroxenous (alternating between invertebrate and vertebrate or plant hosts) genera (Fig. 1). The genera Leishmania and Trypanosoma are responsible for a broad spectrum of human and animal diseases, such as sleeping sickness, Chagas' disease and kala-azar (Vickerman 1994). The genus Endotrypanum is the unique intraerythrocytic parasite of principally forest-dwelling two-toed sloth (Cupolillo et al. 2000). Flagellate trypanosomatids of the genus Phytomonas are etiological agents of diseases affecting various fruits and plants, some of them of great economical importance including coconut, oil palm, tomato, coffee, cassava and corn. However, phytomonads also parasitize lactiferous plants without apparent pathogenicity. Plant flagellates are transmitted to their plant hosts by phytophagous insects, mainly piercing hemipterans (Dollet 1984, Camargo 1999).

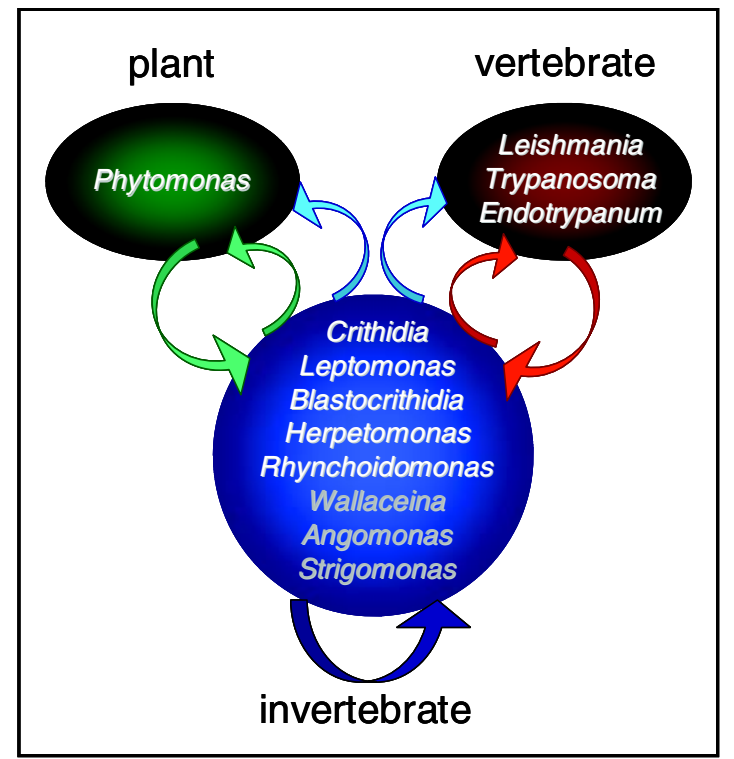

Fig. 1 - The life cycles of the trypanosomatid genera. In the heteroxenous ones, trypanosomatids alternate between an invertebrate host and vertebrates (red arrows) or plants (green arrows). The development of monoxenous genera occurs in a single invertebrate host (dark blue arrow), although insect trypanosomatids can be found in plants and recent reported cases describe the presence of these trypanosomatids in vertebrates (light blue arrows). The insect trypanosomatid genera highlighted in grey were recently proposed.

In addition to these heteroxenous organisms, several genera such as Crithidia, Blastocrithidia, Leptomonas, Herpetomonas and Rhynchoidomonas are restricted to a single host from such widely diverse groups of invertebrates as ciliates, rotifers, nematodes, mollusks, annelids and arachnids, but are found predominantly in insects (Wallace 1966, McGhee and Cosgrove 1980, Vickerman 1994). Insect trypanosomatids have been traditionally allocated to distinct genera that were described based on morphological features, host and geographical origin (Wallace et al. 1983, Momen 2001). However, for identification purposes, these criteria proved to be impractical and insufficient, because different genera share the same evolutive forms (Wallace 1966) and because a diverse range of insects and plants can alberg lower trypanosomatids 
(Catarino et al. 2001). Therefore, the same trypanosomatid species may be recovered from diverse species of insects or plants and the same insect species may harbor various species of trypanosomatids (Momen 2001, Podlipaev 2001). To exemplify this controvert classification, at least three new genera have been proposed, Wallaceina (Podlipaev et al. 1990), Angomonas (Sousa and Côrte-Real 1991, Brandão et al. 2000, d'Avila-Levy et al. 2001, 2004) and Strigomonas (Brandão et al. 2000, d'AvilaLevy et al. 2001, 2004), to accommodate choanomastigote-shaped species bearing features that do not allow their inclusion in Crithidia or other recognized genera.

\section{LOWER TRYPANOSOMATIDS}

Plant trypanosomatids and monoxenous genera informally constitute the "lower trypanosomatids", a denomination that reflects the earlier views based on morphology and life cycles and that considered these species to be the most primitive ones in the Trypanosomatidae family, although this view was reversed in the last decade through molecular data (Vickerman 1994).

The similarity between insect and plant flagellates and the trypanosomatids of mammals have excited the interest of biologists for many years (Wallace 1966, McGhee and Cosgrove 1980, Vickerman 1994, Podlipaev 2000). Several reasons emphasizes the importance of the study of lower trypanosomatids such as their possible use as control agents of vectors or pathogens, their use as models in the study of nutrition, biochemistry, ultrastructure, molecular biology, chemotherapeutic agents, symbiosis and bioassays. Besides, they still might serve as sources of enzymes for biochemical and clinical research, are easily cultured under axenic conditions and are classically nonpathogenic to humans (McGhee and Cosgrove 1980, Vickerman 1994, Podlipaev 2000). Moreover, recent publications reported cases of diffuse cutaneous infection caused by presumed monoxenous trypanosomatids in patients infected with the human immu- nodeficiency virus (HIV), which developed a diffuse "leishmaniasis-like" syndrome with numerous amastigotes in the skin nodules (Chicarro and Alvar 2003). Collectively, the authors affirmed that the immune system depression in the patients might possibly explain the successful colonization by any theoretically nonpathogenic insect trypanosomatid, and also that similar cases could be more frequently detected in the future when HIV infections spread to tropical areas where hematophagous Diptera are frequently infected with monoxenous trypanosomatids (Dedet et al. 1995, Jiménez et al. 1996, Chicarro and Alvar 2003). HIV co-infection with classically nonpathogenic flagellates and with parasites presenting a distinct isoenzyme profile from the known Leishmania spp. are increasing vertiginously, giving rise to clinical manifestations similar to leishmaniasis (Dedet et al. 1995, Alvar et al. 1997, Jiménez et al. 1996, Matlashewski 2001, Chicarro and Alvar 2003). Therefore, these facts emphasize the need to better characterize Leishmania-like parasites isolated from HIV infected patients as well as probable virulence attributes that allow the parasites to interact effectively with invertebrate and vertebrate hosts. In this sense, several studies demonstrated that lower trypanosomatids share common antigenic molecules with pathogenic genera (Souza et al. 1974, 1980, Lopes et al. 1981, Breganó et al. 2003, d'Avila-Levy et al. 2003, 2005a, 2006a, b, Elias et al. 2006, Nogueira de Melo et al. 2006, Santos et al. 2006).

The experimental infection of mammals by insect trypanosomatids has been demonstrated a long time ago (Wallace 1966, McGhee and Cosgrove 1980, Deane and Jansen 1988). For instance, the scent glands of opossums support the growth of several insect trypanosomatids for at least six months (Jansen et al. 1988). It has been recently demonstrated that Crithidia deanei and Herpetomonas roitmani, two symbiont-harboring trypanosomatids, are able to infect and survive in dermal mouse fibroblasts in vitro (Santos et al. 2004). Fibroblasts may be used as a "hiding place" by Leishmania, and probably by other trypanosomatids, en- 
abling them to persist in mammalian hosts, even after the clinical cure of the disease. In addition, it was established that the co-infection of Blastocrithidia culicis and HIV-1 in human monocyte-derived macrophages increased two times the $B$. culicis survival in these monocytes (Fampa et al. 2004). Finally, it was shown that $B$. culicis possesses homologues to virulence factors from Trypanosoma cruzi and Leishmania spp., namely cruzipain and gp63, respectively (d'Avila-Levy et al. 2005a). Taken together, these observations indicate that the life cycle of lower trypanosomatids has been underestimated, and that homologues to virulence factors from classical trypanosomatid pathogens should fulfill a more diverse role for these parasites than previously thought.

Recent advances in our understanding of the biochemistry and molecular biology of the protozoa have focused attention on specific parasite molecules that are essential to the parasite life cycle or the pathogenesis of the diseases they produce. One group of enzymes that plays myriad roles in these processes is the parasite-derived proteases (North 1982, McKerrow et al. 1993, Coombs and Mottram 1997, McKerrow 1999, Cazzulo et al. 2001, Sajid and McKerrow 2002, Yao et al. 2003).

\section{PROTEOLYTIC ENZYMES}

Proteases are degradative enzymes that catalyze the cleavage of peptide bonds in macromolecular proteins and oligomeric peptides. Proteases are the single class of enzymes that occupy a pivotal position with respect to their applications in both physiological and commercial fields (Rao et al. 1998). Proteolytic enzymes play several physiological roles and are essential factors for homeostatic control in both prokaryotes and eukaryotes. They are responsible for the complex processes involved in the normal physiology of the cell as well as in abnormal pathophysiological conditions. Since proteases are physiologically necessary for living organisms, they are ubiquitous, being found in a wide diversity of biological systems such as plants, animals and microor- ganisms (North 1982, McKerrow et al. 1993, Rao et al. 1998, Sajid and McKerrow 2002, Yao et al. 2003).

A redundant set of terms is used by the scientific community to refer to proteolytic enzymes. This includes the terms protease, peptide hydrolase and peptidase. Of these, protease is the most familiar (Barret et al. 2001). According to the Nomenclature Committee of the International Union of Biochemistry and Molecular Biology, proteases are classified in subgroup 4 of group 3 (hydrolases). However, proteases do not comply easily with the general system of enzyme nomenclature essentially because they catalyze the same reaction, i.e., hydrolysis of a peptide bond. The differences between the individual enzymes concern the position of the scissile bond in the peptide chain and the preferred sequence of amino acids around it. From an analysis of their in vitro properties, proteases may be classified on the basis of three major criteria: (i) type of reaction catalyzed, (ii) chemical nature of the catalytic site and (iii) evolutionary relationship with reference to amino acid sequence and protein structure (Barrett 1994, 1995, Rao et al. 1998, Barrett et al. 2001, 2003, Rawlings et al. 2004a).

Proteases are grossly subdivided into two major groups depending on their site of action: exopeptidases and endopeptidades. Exopeptidases cleave the peptide bond proximal to the amino $\left(\mathrm{NH}_{2}\right)$ or carboxy $(\mathrm{COOH})$ termini of the proteinaceous substrate, whereas endopeptidases cleave peptide bonds within a polypeptide chain. Based on their site of action at the $\mathrm{NH}_{2}$ or $\mathrm{COOH}$ terminus, the exopeptidases are classified as amino- or carboxipeptidases, respectively. Aminopeptidases act at a free $\mathrm{NH}_{2}$ terminus of the polypeptide chain and liberate a single amino acid residue, a dipeptide or a tripeptide. Carboxypeptidases act at the $\mathrm{COOH}$ terminal of the polypeptide chain and liberate a single amino acid or a dipeptide. Carboxypeptidases can be further divided into three major groups: serine-, metallo- and cysteine carboxypeptidases, based on the functional group present at the active site of the enzymes. Similarly, endopeptidases (also 
known as proteinases) are classified according to essential catalytic residues at their active sites in: serine-, metallo-, glutamic-, threonine-, cysteineand aspartic endopeptidases. Conversely, there are a few miscellaneous proteases that do not precisely fit into the standard classification (Barrett 1994, Rao et al. 1998, Barrett et al. 2001). The class of a protease is routinely determined according to the effects of proteolytic inhibitors on the enzymatic activity (Rawlings et al. 2004b).

Newly, the MEROPS database (http://www. merops.sanger.ac.uk) provides a catalogue and structure-based classification of proteolytic enzymes and their inhibitors. In this novel classification system, the proteases are grouped into families on the basis of statistically significant similarities between the protein sequences in the part termed 'peptidase unit' that is most directly responsible for activity. Families that are thought to have common evolutionary origins and are known or expected to have similar tertiary folds are grouped into clans (Rawlings and Barrett 2000, Barrett et al. 2001, Rawlings et al. 2002, 2004a, b).

In recent years it has become obvious that proteases and proteolysis play vital roles in the biology of all living cells. Intracellular proteases are important for various cellular and metabolic processes, such as growth, differentiation, death, protein turnover, maturation of enzymes and maintenance of the cellular protein pool. Extracellular proteases are important for the hydrolysis of proteins in cell-free environments and enable the cell to absorb and utilize hydrolytic products (Rao et al. 1998, Barrett et al. 2001). Furthermore, it has also become clear that the non-catalytic effects of membrane-bound proteases are of great importance in some biological regulations. They may generate specific signal transduction events intracellularly, after reacting with certain target molecules (LeMosy et al. 1999). They may also play a pivotal role in cell-to-cell contact and recognition, as well as in the binding to the extracellular matrix (Sedo et al. 1996). On the other hand, membrane-bound proteases may exert autocrine and paracrine effects in their immediate pericellular microenvironment (Nadel 1992).

Proteases are also used currently as reagents in laboratory, clinical and industrial processes, and their involvement in the life cycle of disease-causing organisms has led them to become a target for developing therapeutic agents against fatal diseases (Wolf 1992, McKerrow et al. 1993, Roose and van Noorden 1995, Rao et al. 1998, McKerrow 1999, Miyoshi and Shinoda 2000, Barrett et al. 2001, Cazzulo et al. 2001, Lecaille et al. 2002, Bode and Maskos 2003). In contrast to the multitude of the roles contemplated for proteases, our knowledge about the mechanisms by which they perform these functions is very limited. Therefore, extensive research is being carried out to unravel the metabolic pathways in which proteases play an integral role.

\section{PROTEASES PRODUCED BY TRYPANOSOMATIDS: AN OVERVIEW}

Over the past few years it has become increasingly clear that proteases produced by the pathogenic trypanosomatids (especially T. cruzi and Leishmania spp.) play an important role in several steps of the host infection including: adsorption, penetration, intracellular survival, replication, differentiation, infectivity, immune evasion and nutrition. Trypanosomatids elaborate a large array of proteases, which are intracellular and/or extracellular, with different specificities and many of them have been purified and characterized and their genes cloned and sequenced. Because of their unusual structural features, parasite proteases are considered to have a high potential as targets for novel antiparasitic agents. The immunodominant nature of many proteases offers potential for serodiagnosis and vaccine development. The developmentally regulated expression of various proteases suggests that they possess specific functions within the individual life cycle stages (North 1982, McKerrow et al. 1993, Medina-Acosta et al. 1993, Coombs and Mottram 1997, McKerrow 1999, Sajid and McKerrow 2002, Soares et al. 2003, Yao et al. 2003).

Furthermore, the studies of trypanosomatid 
proteases are merited because they may serve as a model for understanding the function and evolution of proteases in general. Comparison of amino acid sequences, three-dimensional structures and the biochemical mechanism of action of proteases assist in deciphering of their course of evolution (MedinaAcosta et al. 1993, Rawlings et al. 2002, 2004a). In this sense, changes in molecular structure have accompanied the demands for altered functions of proteases during evolution (Rao et al. 1998). In trypanosomatids, the most widely distributed and highly active are the metallo- and cysteine proteolytic enzymes (North 1982, McKerrow et al. 1993, Branquinha et al. 1994b, 1996, Santos et al. 2005). One of the most notorious proteolytic enzymes is a $63 \mathrm{kDa}$ metalloprotease (gp63) detected in all Leishmania species, which constitutes the goal of our present revision.

\section{GP63 FROM Leishmania}

Parasites belonging to the genus Leishmania are transmitted to the animal host through the bite of an infected sand fly. Upon gaining access to the host, the metacyclic promastigote forms of the parasite invade host macrophages and differentiate to the amastigote forms. Amastigotes replicate within macrophages, burst out and reinfect new macrophages. The life cycle is completed when the sand fly ingests amastigotes while feeding on an infected host. In the insect gut, amastigotes differentiate to the replicative form, the procyclic promastigote. Depending on the infecting species, human leishmaniasis can range from a relatively mild cutaneous lesion to a visceral infection (kala-azar) that can be fatal if untreated (Herwaldt 1999).

The surface of all parasites usually undergoes considerable changes during their life cycle. This is of special interest in the case of the parasitic protozoa of the genus Leishmania whose surface is exposed to different environments within the vertebrate and invertebrate hosts. In view of the importance played by the cell surface of pathogenic protozoa for their interaction with the host, some effort has been devoted to its characteriza- tion (Branquinha et al. 1994a, De Souza 1995, Descoteaux and Turco 1999, Ilgoutz and McConville 2001). In this context, a number of molecules have been shown to be important factors in the virulence of Leishmania species. Three major surface molecules, lipophosphoglycan (LPG), glycosylinositolphospholipids (GIPLs) and the zinc metalloprotease gp63, are the most studied (Descoteaux and Turco 1999, Ilgoutz and McConville 2001, Yao et al. 2003).

Leishmanolysin, promastigote surface protease (PSP), major surface protease (MSP), EC 3.4.24.36 or gp63 are the designations to the most abundant surface glycoprotein of Leishmania spp. (Etges et al. 1986), which is distributed over the entire surface of the promastigote forms, including the flagellum (Fong and Chang 1982, Yao et al. 2003). Each Leishmania major promastigote in the stationary phase is estimated to have 500,000 copies of gp63, constituting about $1 \%$ of the organism's total protein content (Bouvier et al. 1985). This protein is synthesized in the endoplasmic reticulum, where the signal sequence is cleaved posttranslationally, a N-linked carbohydrate is added and the C-terminal (approximately 25 amino acid residues) are replaced with a glycosylphosphatidylinositol (GPI) membrane anchor structure. Subsequent proteolytic processing involves the cleavage of a pro-peptide, to produce the mature polypeptide chain. The predicted pro-peptide contains a cysteine residue that is conserved in all gp63 across species. In $L$. major this residue has been shown to contribute to a cysteine switch mechanism, modulating the binding of the zinc atom at the active site and regulating the enzyme activity, which is a presumed mechanism that protects the parasite cell from self-destruction by active gp63 (Macdonald et al. 1995).

Resembling most trypanosomatids surface molecules, the majority of gp63 is anchored to the promastigote membrane via a GPI anchor (Bordier et al. 1986). Experiments using surface biotinylation, cytofluorimetry and immunoelectron microscopy showed that three-fourths of Leishmania mexicana 
gp63 occurs on the cell surface, whereas the remainder is located intracellularly (Weise et al. 2000). Moreover, gp63 is also released by promastigotes to the extracellular medium in both membrane-associated and free forms. Antibody-induced capping on living cells demonstrated that the surface protease is free to move in the plane of the membrane, concentrating first at the ends of the cells, and then being released into the medium (Fong and Chang 1982, Chang et al. 1986). Although the GPI anchor can be cleaved with phospholipase C (PLC) revealing the cross-reacting determinant (CRD) epitope, evidence using antibody against CRD indicates the GPI anchor is not enzymatically cleaved in vivo during the release from the Leishmania cell (McGwire et al. 2002, Yao et al. 2002). It was demonstrated that the release of Leishmania amazonensis gp63 into the extracellular environment was powerfully reduced in the presence of a metal chelator, 1,10phenanthroline, or in the case of gp63 mutation at the zinc-binding motif. This suggests that gp63 release is dependent on autoproteolysis (McGwire et al. 2002).

All gp63 studied to date in the different Leishmania species share high nucleotide sequence identity and the enzyme has been shown to be encoded by a family of tandemly linked genes, all of which map to a single chromosome (Button and McMaster 1988, Button et al. 1989). Additionally, the crystal structure of gp63 purified from L. major promastigotes reveals that this protease is a member of the metzincin family of zinc metalloproteases, with

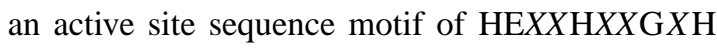
(Schlagenhauf et al. 1998). Structural studies indicate that the gp63 likely exist as homodimers, and both amphiphilic and hydrophilic forms have been found in the same cell (Bouvier et al. 1989). As described above, several Leishmania spp. contain distinct classes of gp63 genes that are developmentally regulated in different parasite life cycle stages, including the amastigote, logarithmic promastigote and metacyclic promastigote forms (Medina-Acosta et al. 1993). Consequently, gp63 plays vital roles in the different stages of Leishmania life cycle. For in- stance, membrane-bound gp63 expression by amastigotes is much reduced, although a soluble form of gp63 is expressed within the lysosome of the parasite (Medina-Acosta et al. 1989, Schneider et al. 1992, Ilg et al. 1993).

gp63 has a wide substrate specificity and optimum pH (Chaudhuri and Chang 1988, Bouvier et al. 1989, Schneider and Glaser 1993). The gp63 optimum pH may vary among Leishmania spp. (Tzinia and Soteriadou 1991) and may diverge depending on the substrate and assay method employed (Ilg et al. 1993). In addition, it is an endopeptidase with no exopeptidase activity, capable to hydrolyze several proteinaceous substrates in vitro including serum proteins such as albumin, casein, complement components, fibrinogen, hemoglobin and immunoglobulins (Bouvier et al. 1990), as well as extracellular matrix components such as type IV collagen and fibronectin, which could facilitate the migration through the subendothelial basement membrane, facilitating the dissemination of the parasite in the tissues (McGwire et al. 2003). On the other hand, the in vivo substrates of gp63 are unknown.

Several possible additional roles were suggested for the gp63 molecule when the promastigote is inside the mammalian host: (i) it helps promastigote evasion of complement-mediated lysis, by cleaving $\mathrm{C} 3$ to its breakdown products (Chaudhuri and Chang 1988) as well as converting C3b to the inactive form iC3b (Brittingham et al. 1995), (ii) it enhances phagocytosis of promastigotes through macrophage receptors such as CR3 (Mosser and Edelson 1987, Russell et al. 1989, Brittingham et al. 1995), (iii) it contains the sequence SRYD that is antigenically related to the RGDS sequence of fibronectin, suggesting a potential interaction of gp63 with macrophage fibronectin receptors (Soteriadou et al. 1992), (iv) it promotes degradation of host cytosolic MARCKS-related protein (Corradin et al. 1999), (v) it is capable of cleaving surface CD4 and could diminish T cell responses (Hey et al. 1994) and (vi) it also cleaves intracellular peptides presented by MHC class I molecules (Garcia et al. 1997). 
gp63-like molecules have been described in other human pathogenic trypanosomatids, including Trypanosoma brucei and T. cruzi. In the former, it was suggested that a metalloprotease surface activity is responsible for the shedding of variant surface glycoprotein (VSG) during cellular differentiation (Bangs et al. 2001). In fact, one of the $T$. brucei gp63 gene families is involved in the release of transgenic VSG from procyclic cells (Lacount et al. 2003). T. cruzi possesses a family of gp63 genes composed of multiple groups (Cuevas et al. 2003). Two of these groups, Tcgp63-I and -II, are present as high-copy-number genes and antibodies against Tcgp63-I partially blocked the infection of Vero cells by trypomastigotes, which suggests a possible role for this metalloprotease during the infection process in vitro (Cuevas et al. 2003).

Despite gp63 being one of the best characterized surface molecules of Leishmania, its precise role in the life cycle of the parasite during the insect colonization remains under speculation. In this context, gp63 is predominantly present on the surface of promastigotes residing in the midgut of the phlebotomine sandfly vector (Grimm et al. 1987, Davies et al. 1990). However, data from gp63 knockouts in L. major do not support a major role for gp63 in parasite survival in the insect, since the number of metacyclic promastigotes in the anterior gut of Phlebotomus dubosqui infected with either the knockouts or the wild type was comparable (Joshi et al. 2002). Conversely, Hajmová et al. (2004) reported that the down-regulation of gp63 in a L. amazonensis clone adversely affects its early development in the neotropical Lutzomyia longipalpis sand fly. The possibility exists that gp63 may function differently for these two distinct Leishmania species in their interactions with different invertebrate vector species.

gp63 homologues have been initially detected in the monoxenous insect trypanosomatids, suggesting a primary role for the parasite survival in the insect gut (Etges 1992, Inverso et al. 1993). Therefore, some insights into gp63 functions may be gained through studies of homologues of the
Leishmania proteins in lower trypanosomatids.

\section{GP63-LIKE METALLOPROTEASE FROM LOWER TRYPANOSOMATIDS}

The first report on the presence of surface metalloproteases with biochemical similarities to the gp63 was on Crithidia fasciculata and Herpetomonas samuelpessoai (Etges 1992). It was shown that these parasites display a neutral-to-alkaline surface metalloprotease capable to degrade fibrinogen when incorporated on sodium dodecyl sulfate-polyacrylamide gel electrophoresis (SDS-PAGE), in a similar way to several Leishmania species (Etges 1992). The presence of a functionally conserved metalloprotease at the surface of Crithidia and Herpetomonas led the authors to suggest that the gp63 should not be involved in the infection of the mammalian host by Leishmania, but would rather contribute to the survival of the protozoan inside the digestive tract of the insect. Interestingly, the pattern of membrane metalloprotease activity and surface iodination displayed by motile $C$. fasciculata is distinct from that of the adherent form, suggesting that the expression of surface protease is developmentally regulated, as detected in Leishmania (Etges 1992). One year later, Inverso et al. (1993) have demonstrated the presence of a gene from $C$. fasciculata with homology to the gp63 metalloprotease gene of Leishmania. The C. fasciculata gene homologue is arranged as a multicopy family comprised of approximately 7 distinct genes, where the mature transcript possesses $4.0 \mathrm{~kb}$ and the predicted amino acid sequence contained a zinc-binding motif and a potential site for addition of a GPI membrane anchor. The authors supported the hypothesis that gp63 primary, or ancestral, function should be related to survival within the dipteran host (Inverso et al. 1993).

Other similarities between Leishmania gp63 and the surface metalloprotease from $H$. samuelpessoai were demonstrated, such as the presence of a GPI anchor, surface location and activity, sensitivity to 1,10-phenanthroline and peptide bond preference (Schneider and Glaser 1993). Promastigotes 
of $H$. samuelpessoai were the subject of research again in 2002 by our group, showing that a minor proportion of the $63 \mathrm{kDa}$ metalloprotease expressed on the surface of $H$. samuelpessoai was also detected in the aqueous phase (cytoplasmic content) after Triton X-114 extraction (Fig. 2), which may indicate either the occurrence of hydrophilic isoforms or the detection of enzymatic activity from precursor molecules that are further transported to the plasma membrane (Santos et al. 2003). For instance, L. mexicana amastigotes express a lysosomal protein, which is antigenically related to the surface gp63, although an acidic optimum $\mathrm{pH}$ was observed (Ilg et al. 1993). Transcripts found predominantly in promastigotes predict a hydrophobic sequence at the COOH-terminus, serving as a GPI anchor addition signal, while highly homologous mRNA in amastigotes codes for a $\mathrm{COOH}$ terminal extension lacking this signal (Bahr et al. 1993).

H. samuelpessoai cells were also able to release the surface $63 \mathrm{kDa}$ metalloprotease to the extracellular environment (Fig. 2) (Santos et al. 2002a). Additionally, three distinct proteolytic bands comigrating around the $63 \mathrm{kDa}$ region were observed after PLC treatment of fixed cells, indicating that this enzyme is probably expressed on the cell surface of $H$. samuelpessoai by distinct isoenzymes (Fig. 3) (Santos et al. 2002a). Differences in migration of the gp63 on SDS-PAGE could be explained by a heterogeneity resulting from posttranslational modifications of a common precursor, such as glycosylation (Bordier et al. 1986). In this context, the gp63 protein obtained from $H$. samuelpessoai was able to bind to Concanavalin A agglutinin; this fact can be attributed to its glycoprotein nature (Santos et al. 2001b). Curiously, H. samuelpessoai gp63 is also endogenously biotinylated (Santos et al. 2001b).

Recently, Elias et al. (2006) demonstrated an immunological cross-reactivity between the $H$. $s a$ muelpessoai released metalloprotease and gp63 using anti-gp63 from L. amazonensis polyclonal antibodies in Western blotting, flow cytometry and fluorescence microscopy analyses. Intriguingly, two distinct populations with different affinities for the anti-gp63 antibody were clearly identified in $H$. samuelpessoai, indicating that gp63-like molecules are not equally expressed on the surface of parasite cells. The occurrence of distinct subpopulations with differential expression of surface gp63 has also been described in C. deanei and Crithidia guilhermei (d'Avila-Levy et al. 2006a, C.M. d'Avila-Levy et al., unpublished data). The lack of equal expression may be correlated to the parasites growth phase, since flagellate cultures were not synchronized. Furthermore, the occurrence of distinct subpopulations could alternatively denote a different expression of surface gp63-like molecules in the different developmental stages (Santos et al. 2003) or even a diminished accessibility to external ligands in cell subsets, as previously reported for other trypanosomatid cell surface molecules (Matta et al. 1995, Santos et al. 2002b, d'Avila-Levy et al. 2005b).

Trypanosomatid parasites shed many molecules into their environment. The mechanisms of release and functions that these enzymes and antigens play in parasite survival and nutrition are mostly unknown. In $H$. samuelpessoai, the release of the gp63-like metalloprotease from the parasite surface was inhibited by the metalloprotease inhibitor 1,10-phenanthroline in a dose-dependent manner, while the PLC inhibitor ( $p$-chloromercuriphenylsulfonic acid) did not alter the secretion pattern. Moreover, anti-CRD antibody failed in recognizing any secreted polypeptide from $H$. samuelpessoai (Elias et al. 2006). Collectively, these results suggest that gp63 molecule was released from the parasite surface by proteolysis instead of phospholipolysis, a similar mechanism to that observed in Leishmania. In this regard, the GPI-anchored gp63 molecule may be released from Leishmania cells by two mechanisms that follow the classic secretory pathway, with routing of gp63 from the endoplasmic reticulum to the Golgi network and then into the flagellar pocket. Vesicles containing both membrane-bound and free gp63 fuse with the flagellar pocket membrane, and thereafter the free gp63 is 


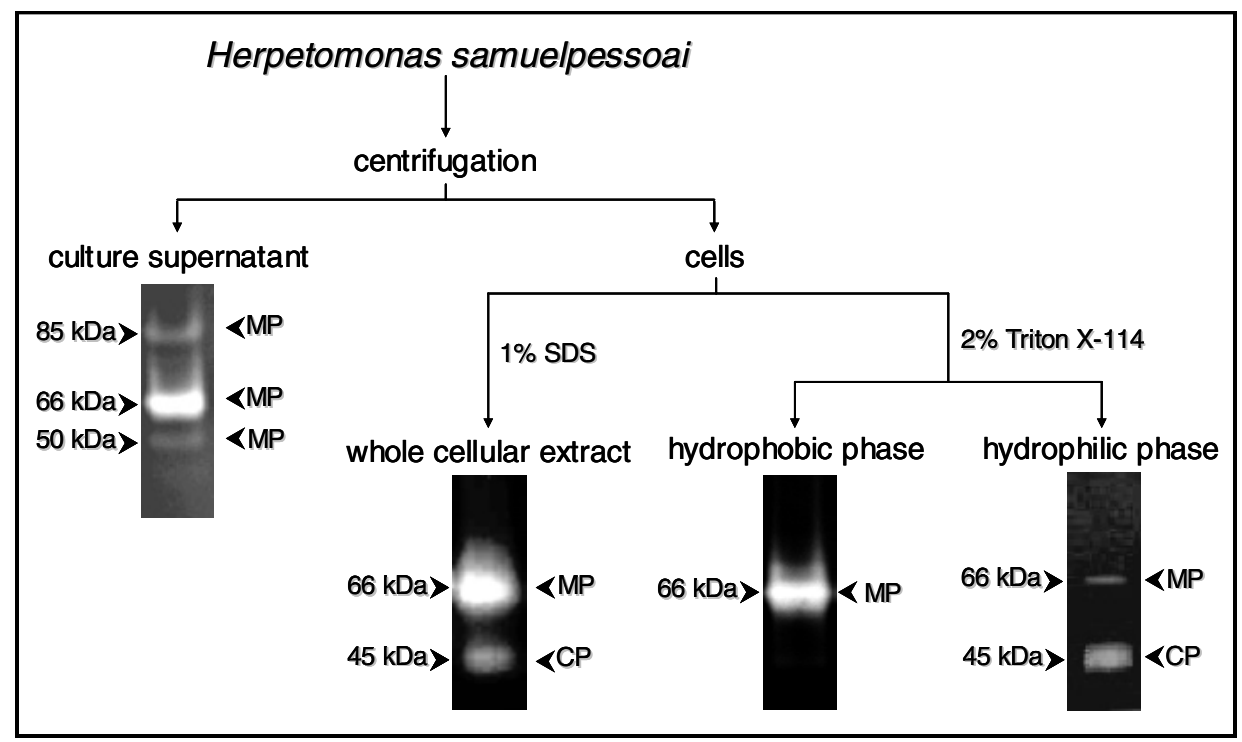

Fig. 2 - Extracellular and cell-associated proteolytic enzymes of Herpetomonas samuelpessoai cells. Parasites were cultured in a complex medium (brain heart infusion) for $48 \mathrm{~h}$ at $26^{\circ} \mathrm{C}$. Then, cells were harvested by centrifugation, the culture supernatant was filtered in Millipore membrane and concentrated 50-fold in Amicon system. The cells were lysed by: the addition of SDS, generating whole cellular extract, or by Triton X-114 to obtain the hydrophilic (cytoplasmatic and intravesicular fraction) and hydrophobic (membrane fraction) phases. The extracellular and cellular extracts were applied on gelatin-SDS-PAGE to evidence the proteolytic enzymes. MP, metalloprotease and CP, cysteine protease. For experimental details see Santos et al. 2002a, 2003. Note that the $66 \mathrm{kDa}$ proteolytic enzyme, presenting metalloprotease activity, was mainly detected in the culture supernatant (extracellular environment) and in the membrane fraction, while a minor proportion was also evidenced in the intracellular compartment.

released extracellularly, while the membrane-bound form is located throughout the external cell membrane, and a proportion of this is released directly via proteolysis (McGwire et al. 2002, Yao et al. 2002). The evolutionary proximity of Herpetomonas spp. to important human pathogens, such as Leishmania, is possibly reflected in the similarity of some aspects of the basic cellular machinery (Tetaud et al. 2002, Hughes and Piontkivska 2003).

Purification of proteases to homogeneity is a prerequisite for studying their mechanisms of action. In this sense, vast numbers of purification procedures for proteases have been well documented, such as affinity, ion exchange and gel filtration chromatographs. Purification of insect trypanosomatid proteases was carried out from culture filtrates of $C$. guilhermei (Nogueira de Melo et al. 2001), C. deanei (d'Avila-Levy et al. 2003) and Phy- tomonas françai (Almeida et al. 2003) by different chromatographic methodologies. Table I summarizes some biochemical properties displayed by the released metalloproteases from $C$. deanei, C. guilhermei and $P$. françai. Figure 4 shows a schematic representation of the purification of the $C$. deane $i$ gp63-like extracellular metalloprotease (d'AvilaLevy et al. 2003).

A small number of trypanosomatids present bacterium endosymbionts in the cytoplasm, which constitute an excellent model to study the symbiosis phenomenon. In trypanosomatids, the possibility of elimination of the endosymbiont by antibiotic treatment (cure) has increased the interest in the study of endosymbiont-harboring species, since several bacterium-protozoan interactions can be analyzed by the comparison of endosymbiont-containing and endosymbiont-free populations of the same 


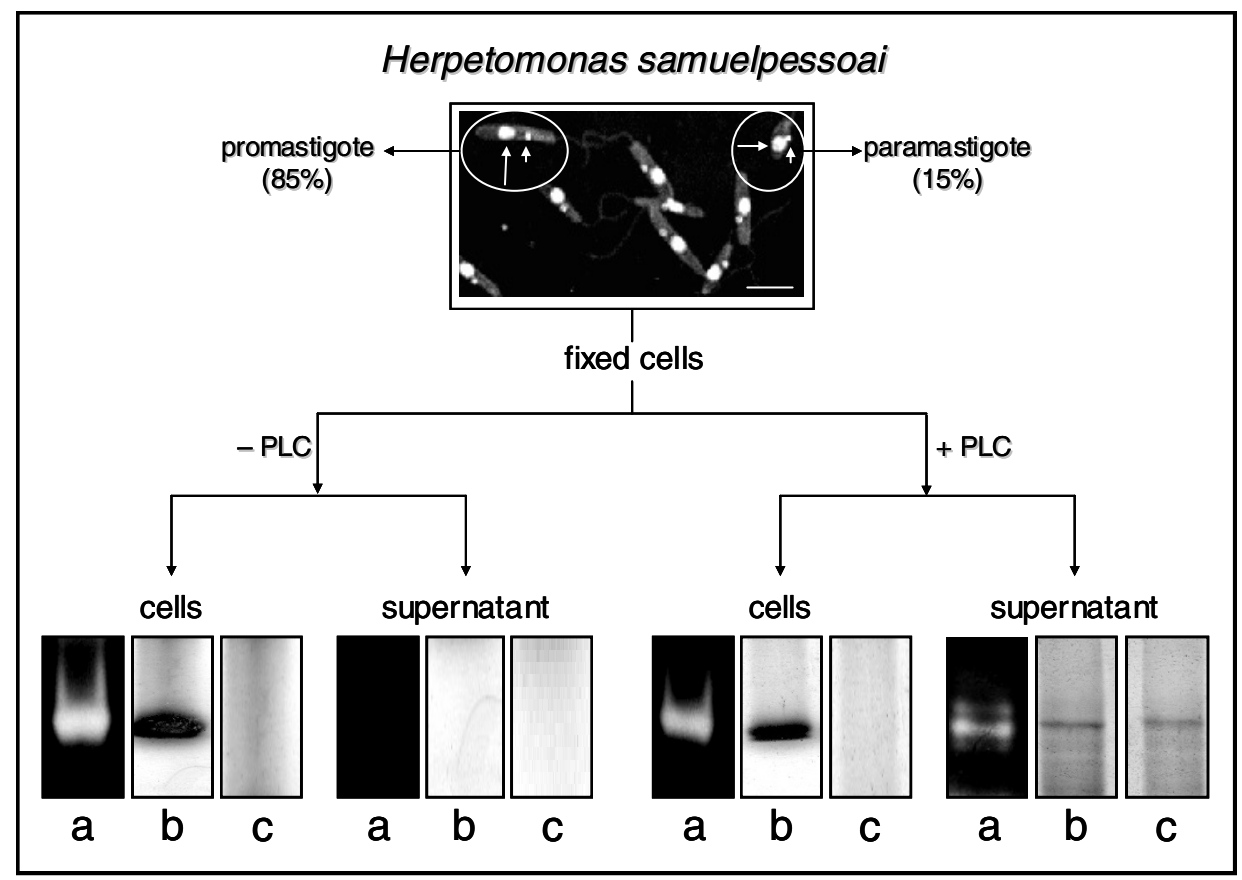

Fig. 3 - Effect of exogenous phospholipase C (PLC) on the cell surface of Herpetomonas samuelpessoai cells. The fluorescence microscopy shows the different evolutive stages incubated with DAPI to evidence the nucleus (arrows) and kinetoplast (arrowheads). Parasites were fixed with paraformaldehyde and then incubated in the absence (-) or in the presence (+) of $0.1 \mathrm{U} / \mu \mathrm{L}$ of PLC in $100 \mu \mathrm{L}$ of PBS supplemented with $20 \%$ glycerol for $3 \mathrm{~h}$ at $37^{\circ} \mathrm{C}$. The mixtures were then harvested by centrifugation and the supernatants from the reaction mixtures were collected and filtered in a $0.22 \mu \mathrm{m}$ membrane. The cells were lysed by Triton X-114 to obtain the membrane-rich fraction. The membrane extracts and the supernatants were then analyzed by gelatin-SDS-PAGE (a), Western blotting probed with anti-gp63 antibody (Chang and Chang 1986) at 1:1000 (b) or anti-CRD antiserum at 1:400 (c). For experimental details see Santos et al. 2002a and Elias et al. 2006. Note that the PLC treatment significantly reduced the surface metalloprotease activity due to the cleavage of the GPI anchor, releasing three distinct metalloproteases to the extracellular medium (reaction mixture) that were recognized by both antibodies.

species (De Souza and Motta 1999). The available data in the literature indicate that the presence of the endosymbiont induces morphological changes, interferes with several aspects of the metabolism of the trypanosomatid and modulates the surface properties of the protozoan (De Souza and Motta 1999, d'Avila-Levy et al. 2001, 2005b). Our group showed that the aposymbiotic strain of $C$. deanei expressed reduced levels of the gp63-like molecule on the cell surface (C.M. D'Avila-Levy et al., unpublished data). Conversely, this strain releases higher amounts of the extracellular metalloprotease, suggesting a regulation of this metallo-type enzyme by the presence of the endosymbiont (d'Avila-Levy et al. 2001, 2003).

Although direct evidence has never been obtained, it has been suggested that the gp63-like molecules from lower trypanosomatids might fulfill a nutritional role in the insect midgut (Inverso et al. 1993), since insect colonization is believed to be the only life cycle stage common to the monoxenous and heteroxenous flagellate trypanosomatids (Fig. 1). Several methods have been described for protease detection by SDS-PAGE, including incorporation of different substrates within the gel prior to electrophoresis (Fig. 5). In this context, a $62 \mathrm{kDa}$ 
TABLE I

Biochemical features displayed by the released metalloproteases purified and characterized from Crithidia deanei (cured strain) (d'Avila-Levy et al. 2003), Crithidia guilhermei (Nogueira de Melo et al. 2002) and Phytomonas françai (Almeida et al. 2003).

\begin{tabular}{|c|c|c|c|}
\hline Biochemical features & Crithidia deanei & Crithidia guilhermei & Phytomonas françai \\
\hline $\mathrm{pH}$ & \multicolumn{3}{|c|}{ Proteolytic activity $(\%) *$} \\
\hline 5.0 & 46 & 99 & 100 \\
\hline 6.0 & 100 & 100 & 67 \\
\hline 7.0 & 30 & 42 & 17 \\
\hline Temperature & \multicolumn{3}{|c|}{ Proteolytic activity $(\%) *$} \\
\hline $26^{\circ} \mathrm{C}$ & 76 & 17 & 100 \\
\hline $37^{\circ} \mathrm{C}$ & 100 & 100 & 69 \\
\hline Inhibition profile ${ }^{\#}$ & \multicolumn{3}{|c|}{ Proteolytic activity $(\%) *$} \\
\hline PMSF & 74 & 80 & 78 \\
\hline STI & 76 & 76 & 53 \\
\hline Aprotinin & 84 & 95 & ND \\
\hline Iodoacetamide & 100 & 100 & ND \\
\hline E-64 & 60 & 55 & 55 \\
\hline 1,10-Phenanthroline & 0 & 0 & 0 \\
\hline EDTA & 12 & 38 & 9 \\
\hline Pepstatin A & 100 & 100 & ND \\
\hline Electrophoretic analysis & \multicolumn{3}{|c|}{ Molecular mass (in kDa) } \\
\hline SDS-PAGE & 62 & 62 & 67 \\
\hline Gelatin-SDS-PAGE & 60 & 67 & 70 \\
\hline
\end{tabular}

*The results are expressed as relative percentage, and maximal proteolytic activity is shown as $100 \%$. \#Serine protease inhibitors: phenylmethylsulfonyl fluoride (PMSF), soybean trypsin inhibitor (STI) and aprotinin. Cysteine protease inhibitors: iodoacetamide and trans-epoxysuccinyl-L-leucylamido-(4-guanidino) (E-64). Metalloprotease inhibitors: 1,10-phenanthroline and ethylenediaminetetraacetic acid (EDTA). Aspartic protease inhibitor: pepstatin A.

ND - Not determined.

purified extracellular metalloprotease from C. guilhermei (Nogueira de Melo et al. 2001), which reacted with anti-gp63 polyclonal antibodies and is also expressed at the parasite cell surface (d'AvilaLevy et al. 2006a), hydrolyzed hemoglobin that may serve as a source of exogenous iron and heme for the parasite (Nogueira de Melo et al. 2002), being these compounds essential metabolites for trypanosomatid development (Wallace 1966, Chang et al. 1975). Similar results were obtained in $B$. culicis, displaying a $55 \mathrm{kDa}$ cell-associated metal- loprotease, which was recognized by the anti-gp63 antiserum and cleaved hemoglobin and albumin (Santos et al. 2001a, d'Avila-Levy et al. 2005a). Indeed, the ability of gp63-like molecules to hydrolyze such a wide range of substrates has made it a convenient enzyme employed by these trypanosomatids to interact with molecules encountered in diverse host or vector environments.

The prevailing $\mathrm{pH}$ range of the insect gut (pH 6.0-7.0), the natural habitat for Herpetomonas and Crithidia species (McGhee and Cosgrove 1980), 


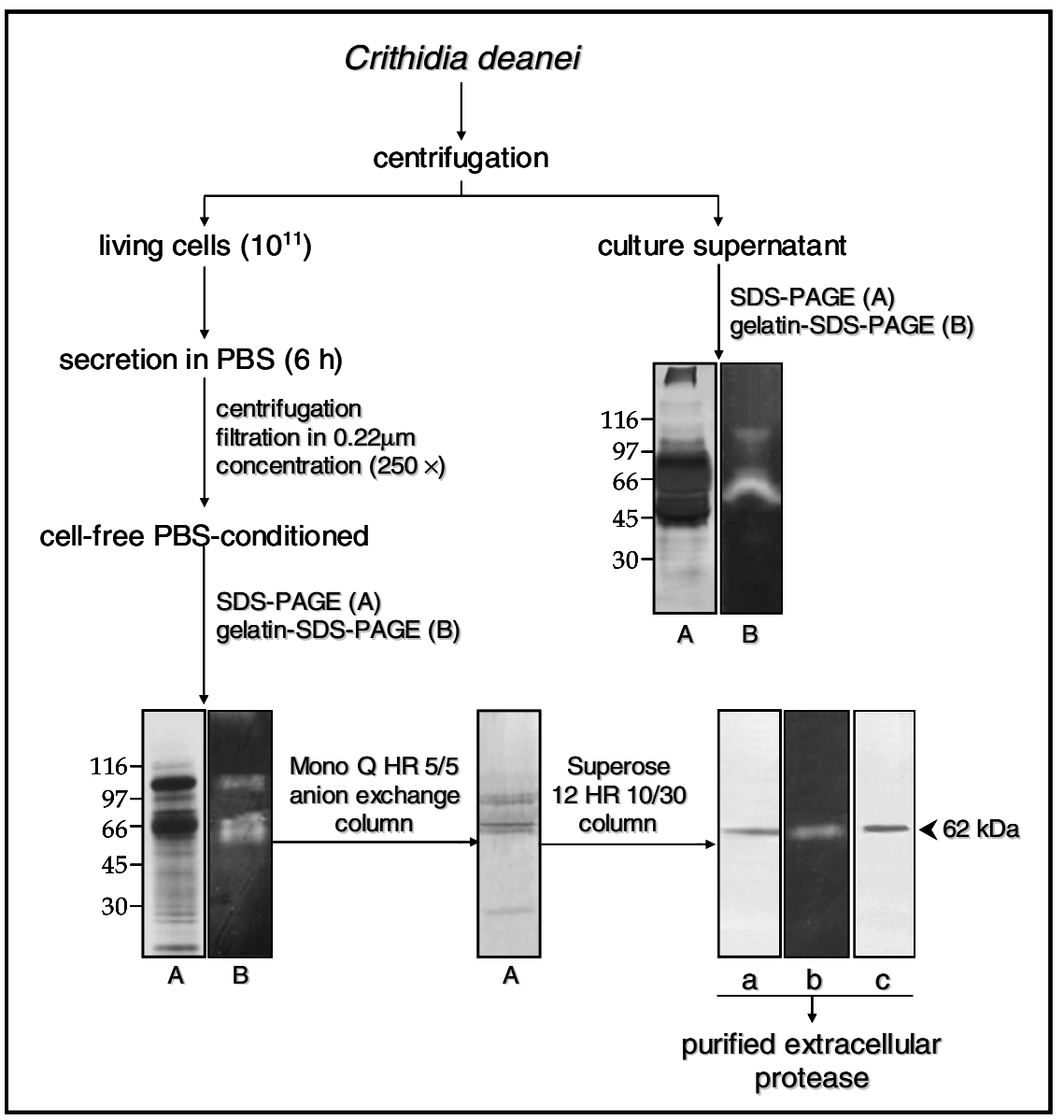

Fig. 4 -Scheme of the strategy employed for the purification of a gp63-like extracellular protease from Crithidia deanei (aposymbiotic strain) (d'Avila-Levy et al. 2003). The comparison of the protein (A) and proteolytic (B) profiles of secreted polypeptides from the spent culture medium supernatant and from the supernatant obtained from secretion in phosphate buffered saline (PBS) shows that the latter eliminates some major protein contaminants, without significant alteration in the proteolytic profile. For purification, parasites $\left(10^{11}\right.$ cells) were incubated in $1000 \mathrm{~mL}$ of PBS for $6 \mathrm{~h}$ at $28^{\circ} \mathrm{C}$ and the cell-free PBS-conditioned supernatant was concentrated 250 times by ultrafiltration. The chromatographic separations were done using a fast-performance liquid chromatography (FPLC) coupled to anionic and gel filtration columns. The protein purity was shown by SDS-PAGE (a), the remaining activity demonstrated by gelatinSDS-PAGE (b) and the homology to gp63 verified by Western blotting using anti-gp63 polyclonal antibodies (Chang and Chang 1986) (c). The numbers on the left indicate the position of the molecular mass standards. For experimental details see d'Avila-Levy et al. 2003.

coincide with the optimum $\mathrm{pH}$ range found for $C$. guilhermei (Nogueira de Melo et al. 2001), C. deanei (d'Avila-Levy et al. 2003) and H. samuelpessoai (Santos et al. 2003) metalloproteases. Moreover, we also compared the activity of the $63 \mathrm{kDa}$ metalloprotease at the vertebrate temperature $\left(37^{\circ} \mathrm{C}\right)$ with that observed in the insect vector $\left(26^{\circ} \mathrm{C}\right)$. In- terestingly, at $26^{\circ} \mathrm{C}$, this proteolytic activity was strongly diminished in these three insect trypanosomatids (Santos et al. 2003, Elias et al. 2006). In addition, the gp63 (membrane-bound or released form) in these trypanosomatids was partially restrained by E-64 (Table I), a powerful cysteine protease inhibitor; this could indicate the presence of 

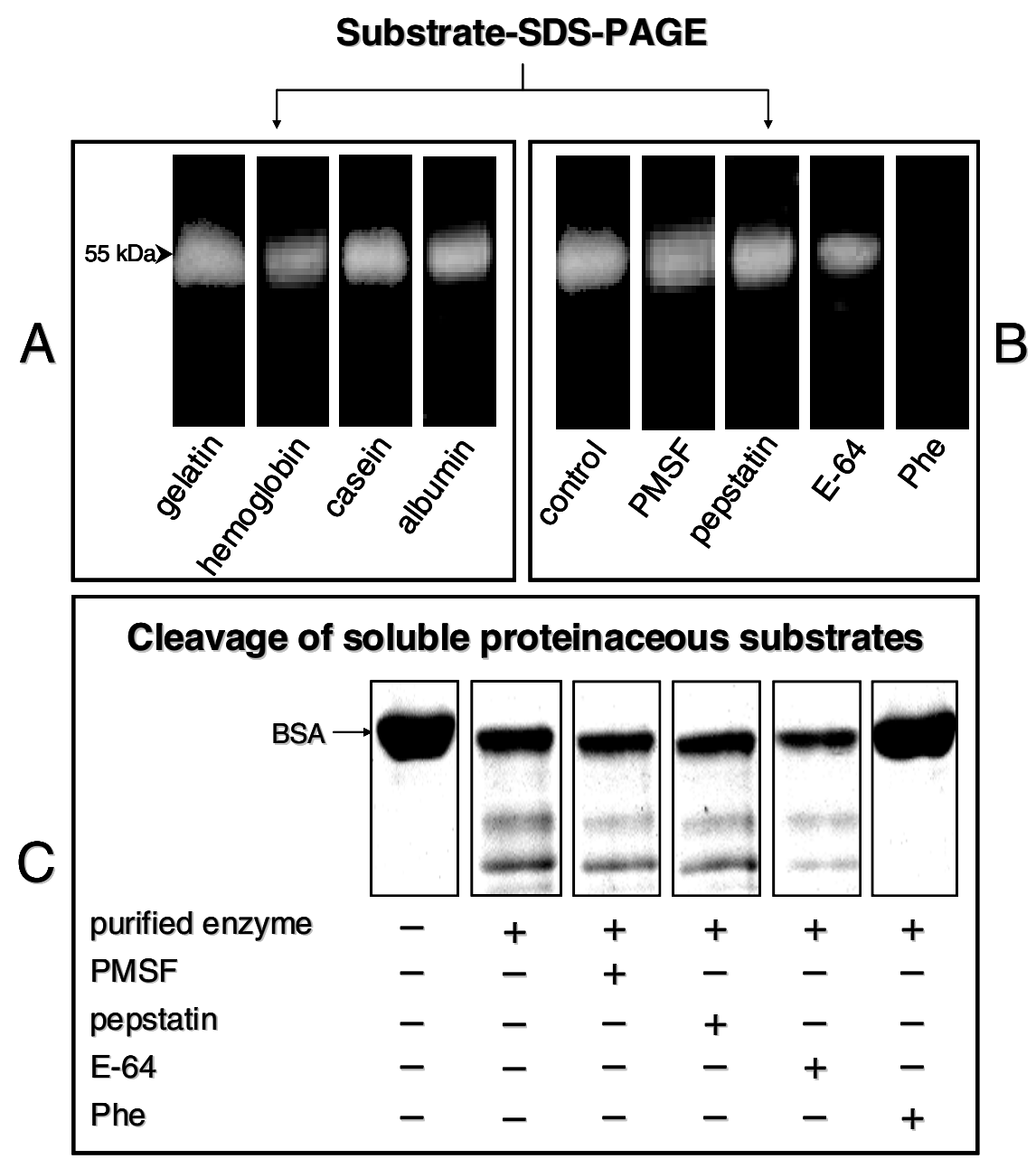

Fig. 5 - Susceptibiliy of different protein substrates to cleavage by the $55 \mathrm{kDa}$ cell-associated purified protease from Blastocrithidia culicis (A). Modulation of the $55 \mathrm{kDa}$ protease activity in the absence (control) or in the presence of different proteolytic inhibitors: $10 \mathrm{mM}$ phenylmethylsulfonyl fluoride (PMSF), $1 \mu \mathrm{M}$ pepstatin, $10 \mu \mathrm{M}$ trans-epoxysuccinyl L-leucylamido-(4-guanidino) butane (E-64) and $10 \mathrm{mM}$ 1,10-phenanthroline (Phe) (B). The gel strips were incubated in phosphate buffer (pH 6.0) for $20 \mathrm{~h}$ at $37^{\circ} \mathrm{C}$. The experiments were executed as described elsewhere (d'Avila-Levy et al. 2003, 2005a, Elias et al. 2006). Alternatively, the purified $55 \mathrm{kDa}$ metalloprotease was mixed with a proteinaceous soluble substrate (in this case, bovine serum albumin - BSA) and incubated at $37^{\circ} \mathrm{C}$ for $5 \mathrm{~h}$ in the absence or in the presence of the above proteolytic inhibitors. In the control lane, BSA was incubated only with PBS. The reaction mixtures were terminated by freezing, and the protein degradation profile was analyzed on SDS-PAGE. For experimental details see Silva et al. 2006.

critical thiol group(s) near the active site (van Wart and Birkedal-Hansen 1988, Macdonald et al. 1995).

Homologues of gp63 were also described, based on biochemical aspects and antibody crossreactivity, either on the cell surface or being released by Crithidia lucilae (Jaffe and Dwyer 2003),
Herpetomonas anglusteri (Fig. 6) (Santos et al. 1999), Herpetomonas roitmani (Santos et al. 1999), Herpetomonas megaseliae (Nogueira de Melo et al. 2006), Leptomonas seymouri (Jaffe and Dwyer 2003), Phytomonas serpens (Vermelho et al. 2003, d'Avila-Levy et al. 2006b) and P. françai (d'Avila- 
Levy et al. 2006a). Curiously, in P. serpens no cellassociated metalloprotease activity was identified by biochemical methods (d'Avila-Levy et al. 2006b), although two cell surface polypeptides migrating at 63 and $52 \mathrm{kDa}$ cross-reacted with antigp63 antibodies (Table II). This explains the agglutination observed in optical microscopy when the parasites were incubated with these antibodies (Fig. 7). In C. lucilae and L. seymouri, the kinetic analysis of gp63 accumulation in the spent culture medium showed that the protease activity increased linearly with growth in culture, peaking prior to the parasites entering the stationary growth phase (Jaffe and Dwyer 2003). Additionally, the gp63-like proteins from C. lucilae (Jaffe and Dwyer 2003), L. seymouri (Jaffe and Dwyer 2003), B. culicis (d'Avila-Levy et al. 2005a), H. samuelpessoai (Elias et al. 2006) and P. serpens (d'Avila-Levy et al. 2006b) were not released through the action of an endogenous PLC, since the polypeptides released in vivo were not recognized by the anti-CRD antibody.

The gp63 of Leishmania spp. is involved in many basic processes including cellular adhesion to mammalian cells (Yao et al. 2003). However, very little is known about the interaction with invertebrate hosts. In this sense, our research group has been using Aedes aegypti as an experimental model for the study of the role of gp63-like molecules on the interaction of lower trypanosomatids with insect guts (Table II). A. aegypti is a very efficient epidemic vector of yellow fever and dengue viruses because of its close association with humans in urban settings, and its blood-feeding behavior of taking blood from multiple human hosts during a single gonotrophic cycle (Gubler 2004). Since monoxenous trypanosomatids have been associated with leishmaniasis-like lesions in immunosuppressed patients (Chicarro and Alvar 2003), the relevance of studying the interaction of monoxenous trypanosomatids and hematophagous insects arises. A. aegypti was also chosen because it has been shown that Herpetomonas sp. is found repeatedly in this insect (Weinman and Cheong 1978). Additionally, it has been established that $B$. culicis and $C$. dea- nei are able to bind to A. aegypti dissected guts in vitro (Fampa et al. 2003, d'Avila-Levy et al. 2005b, 2006a), and that B. culicis can colonize A. aegypti guts (Fampa et al. 2003).

Furthermore, our research group demonstrated the suitability of A. aegypti as an experimental model to study the interaction of trypanosomatids and insects by comparing the interaction of H. megaseliae with its original insect host Megaselia scalaris and $A$. aegypti. It was shown that $H$. megaseliae adheres to the gut of both insects. Curiously, the number of adhered $H$. megaseliae cells was 6 times higher in A. aegypti guts (Nogueira de Melo et al. 2006). Although these data are surprising, they are explainable by the fact that there is not a systematic study on the prevalence of lower trypanosomatids in natural insect populations, only incidental observations (Ebbert et al. 2001). Moreover, some insect trypanosomatids have low host specificity and occupy a large geographical area (Podlipaev 2000). Therefore, M. scalaris may be the insect where $H$. megaseliae was first isolated but not necessarily the most suitable host for this insect trypanosomatid. Finally, a possible role for the gp63like molecules on the adhesive process of this flagellate with both insects was assessed (Table II). Binding assays with explanted guts of insects incubated with purified gp63 and the pre-treatment of trypanosomatids with anti-gp63 antibodies or PLC showed a reduced adhesion of these trypanosomatids to the insect gut wall (Nogueira de Melo et al. 2006).

P. françai is found associated with a disease known as "chochamento das raízes", which means "empty roots", in the latex of cassava (Manihot esculenta Crantz); the disease is characterized by poor root system development and general chlorosis of the aerial part of the plant (Vainstein and Roitman 1986). However, further studies on the transmission are required to demonstrate conclusively the organism's pathogenicity as well as how this trypanosomatid interacts with the invertebrate vector. In comparative studies of our group, we showed that P. françai presents larger amounts of surface gp63- 

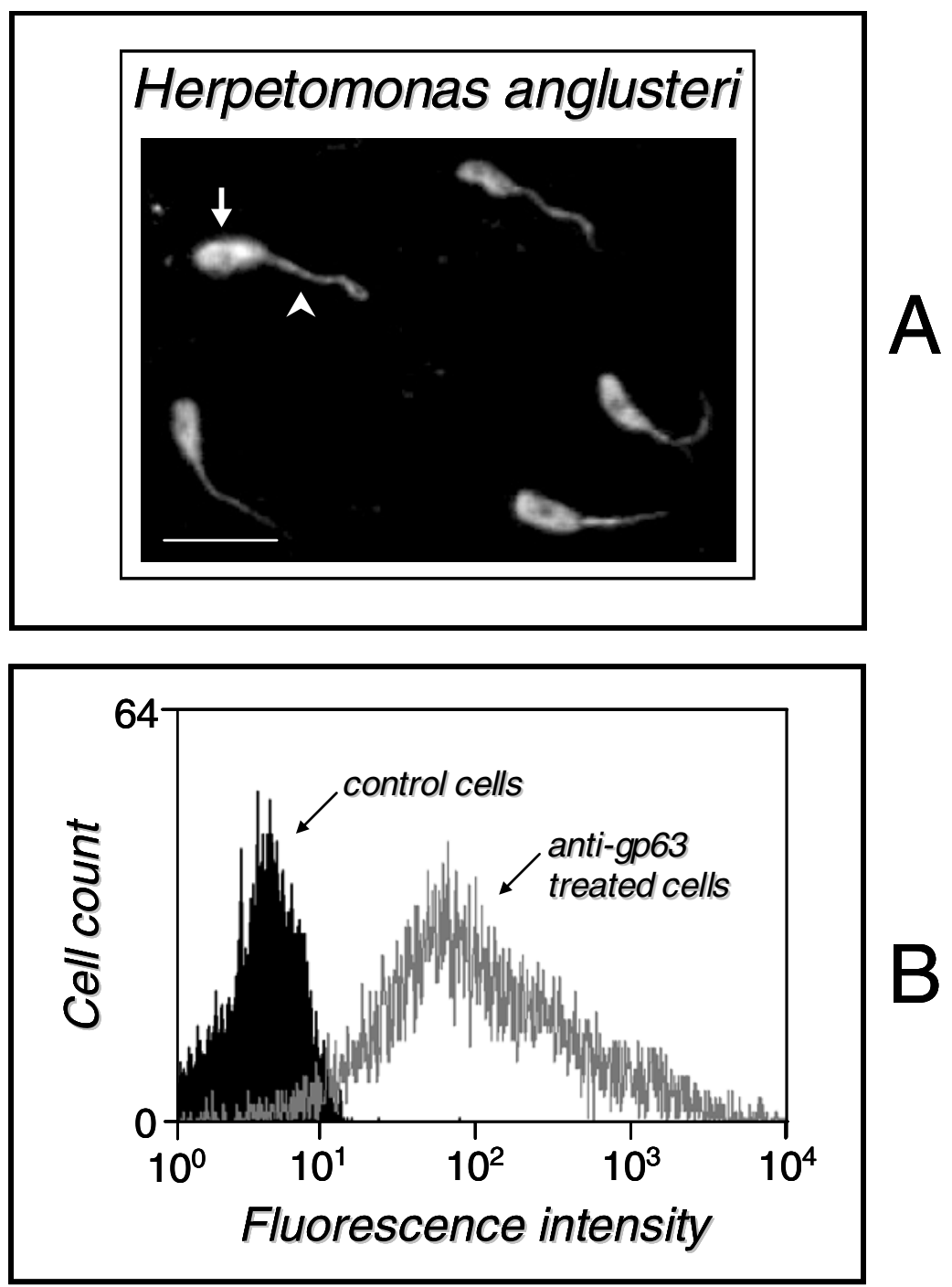

Fig. 6 - Binding of anti-gp63 antibodies (Ilg et al. 1993) to the cell surface of Herpetomnas anglusteri promastigote cells. The fixed parasites were incubated with a 1:250 dilution of rabbit anti-gp63 antibody (anti-gp63 treated cells) or rabbit pre-immune serum (control cells), and then incubated for an additional hour with a 1:250 dilution of fluorescein isothiocyanate (FITC)-labeled goat antirabbit IgG. The cells were then observed in confocal fluorescence microscopy (A) or analyzed by flow cytometry (B). The experiments were performed as described elsewhere (d'Avila-Levy et al. 2006a). The bar represents $10 \mu \mathrm{m}$. Note in $\mathbf{A}$ an intense fluorescence signal for gp63 on both cellular body (arrow) and flagellum (arrowhead).

like molecules in relation to $C$. guilhermei and $C$. deanei (cured strain). Curiously, P. françai interacted more efficiently than both Crithidia species with A. aegypti guts (d'Avila-Levy et al. 2006a). Similarly, the endosymbiont-harboring strain of $C$. deanei presents an enhanced exposition of these surface molecules (C.M. d'Avila-Levy et al., unpublished data) and interaction rates with insect guts and cell lines about two-fold higher than the aposymbiotic strain counterpart (Fampa et al. 2003, d'Avila-Levy et al. 2005b, C.M. d'Avila-Levy et al., unpublished data). The correlation between expres- 


\section{TABLE II}

Presence of gp63 homologues in lower trypanosomatids.

\begin{tabular}{|c|c|c|c|c|c|}
\hline $\begin{array}{l}\text { Trypanoso- } \\
\text { matids }\end{array}$ & $\begin{array}{l}\text { Molecular mass of the } \\
\text { gp63 homologue } \\
\text { protein }(\mathrm{s}) *\end{array}$ & $\begin{array}{l}\text { Presence } \\
\text { of a GPI } \\
\text { anchor }\end{array}$ & $\begin{array}{l}\text { Cell-associated } \\
\text { metalloprotease } \\
\text { activity(ies) }^{\dagger}\end{array}$ & $\begin{array}{c}\text { Role in } \\
\text { invertebrate } \\
\text { adhesion } \ddagger\end{array}$ & Reference(s) \\
\hline $\begin{array}{l}\text { Blastocrithidia } \\
\text { culicis }\end{array}$ & $50(\mathrm{c}, \mathrm{s})$ & + & $50,55,76$ & $\begin{array}{c}\text { not } \\
\text { determined }\end{array}$ & d'Avila-Levy et al. 2005a \\
\hline $\begin{array}{l}\text { Crithidia } \\
\text { deanei }\end{array}$ & $\begin{array}{c}62(\mathrm{c}, \mathrm{s}), \\
67(\mathrm{c})\end{array}$ & + & 51,58 & $\begin{array}{l}\text { Aedes aegypti } \\
\text { (gut) }\end{array}$ & $\begin{array}{l}\text { d'Avila-Levy et al. 2003, } \\
\text { 2006a, C.M. d'Avila-Levy } \\
\text { et al., unpublished data. }\end{array}$ \\
\hline $\begin{array}{l}\text { Crithidia } \\
\text { fasciculata }\end{array}$ & $54(\mathrm{~s})^{a}$ & $++^{a}$ & 59,63 & $\begin{array}{c}\text { not } \\
\text { determined }\end{array}$ & $\begin{array}{l}\text { Etges 1992, } \\
\text { Inverso et al. 1993, } \\
\text { Branquinha et al. } 1996\end{array}$ \\
\hline $\begin{array}{l}\text { Crithidia } \\
\text { guilhermei }\end{array}$ & $\begin{array}{c}62(\mathrm{c}, \mathrm{s}), \\
67(\mathrm{c})\end{array}$ & $\begin{array}{c}\text { not } \\
\text { determined }\end{array}$ & 57,61 & $\begin{array}{l}\text { Aedes aegypti } \\
\text { (gut) }\end{array}$ & $\begin{array}{l}\text { Branquinha et al. 1996, } \\
\text { Nogueira de Melo et al. } 2001 \\
\text { d'Avila-Levy et al. 2006a }\end{array}$ \\
\hline $\begin{array}{l}\text { Crithidia } \\
\text { lucilae }\end{array}$ & $\begin{array}{c}75(\mathrm{~s}), 97(\mathrm{~s}) \\
>100(\mathrm{~s})\end{array}$ & $\begin{array}{c}\text { not } \\
\text { determined }\end{array}$ & 55,61 & $\begin{array}{c}\text { not } \\
\text { determined }\end{array}$ & $\begin{array}{l}\text { Branquinha et al. 1996, } \\
\text { Jaffe and Dwyer } 2003\end{array}$ \\
\hline $\begin{array}{l}\text { Herpetomonas } \\
\text { megaseliae }\end{array}$ & $\begin{array}{c}52(\mathrm{c}, \mathrm{s}) \\
60(\mathrm{c}) \\
63(\mathrm{c})\end{array}$ & + & $50,60,70$ & $\begin{array}{l}\text { Aedes aegypti } \\
\text { (gut) and Mega- } \\
\text { selia scalaris } \\
\text { (gut) }\end{array}$ & $\begin{array}{l}\text { Nogueira de Melo } \\
\text { et al. } 2006\end{array}$ \\
\hline $\begin{array}{l}\text { Herpetomonas } \\
\text { samuelpessoai }\end{array}$ & $63(\mathrm{c}, \mathrm{s})$ & + & $55-66$ & $\begin{array}{l}\text { Aedes aegypti } \\
\text { (gut) } \\
\text { unpublished data }\end{array}$ & $\begin{array}{l}\text { Schneider and Glaser 1993, } \\
\text { Branquinha et al. 1996, } \\
\text { Santos et al. 2003, } \\
\text { Elias et al. } 2006\end{array}$ \\
\hline $\begin{array}{l}\text { Leptomonas } \\
\text { seymouri }\end{array}$ & $97(\mathrm{~s})$ & $\begin{array}{c}\text { not } \\
\text { determined } \\
\end{array}$ & $65,70,78,80$ & $\begin{array}{c}\text { not } \\
\text { determined } \\
\end{array}$ & $\begin{array}{l}\text { Jaffe and Dwyer 2003, } \\
\text { Santos et al. } 2005\end{array}$ \\
\hline $\begin{array}{l}\text { Phytomonas } \\
\text { françai }\end{array}$ & $\begin{array}{l}62(\mathrm{c}) \\
67(\mathrm{c}, \mathrm{s}) \\
\end{array}$ & $\begin{array}{c}\text { not } \\
\text { determined } \\
\end{array}$ & $\begin{array}{c}\text { not } \\
\text { determined } \\
\end{array}$ & $\begin{array}{c}\text { Aedes aegypti } \\
\text { (gut) }\end{array}$ & $\begin{array}{l}\text { Almeida et al. 2003, } \\
\text { d'Avila-Levy et al. 2006a }\end{array}$ \\
\hline $\begin{array}{l}\text { Phytomonas } \\
\text { serpens }\end{array}$ & $\begin{array}{c}52(\mathrm{c}), \\
60(\mathrm{c}, \mathrm{s}) \\
63(\mathrm{c})\end{array}$ & + & $\begin{array}{c}\text { not } \\
\text { detected }\end{array}$ & $\begin{array}{c}\text { Oncopeltus } \\
\text { fasciatus } \\
\text { (salivary gland) }\end{array}$ & $\begin{array}{l}\text { Vermelho et al. 2003, } \\
\text { d'Avila-Levy et al. } 2006 \mathrm{~b}\end{array}$ \\
\hline
\end{tabular}

*The molecular masses of the gp63 homologues (in kDa) were determined by comparison with protein standards after SDS-PAGE and Western blotting using anti-gp63 polyclonal antibodies. The letters (c) and (s) refer to cell-associated and secretory polypeptides, respectively.

${ }^{\#}$ Presence of a GPI anchor (+) was assessed by treating parasites or purified polypeptides with phospholipase C and probing the polypeptides with anti-CRD antibody.

${ }^{a}$ Gene with high homology to the gp63 was cloned and sequenced in C. fasciculata, the gene contains a potential site for addition of a glycosylphosphatidylinositol anchor.

$\dagger$ The numbers indicate the relative molecular masses in kilodaltons of metalloproteases detected by gelatin-SDS-PAGE.

¥ The possible role of the surface gp63 homologues in adhesion to the invertebrate hosts was determined by the approaches described in figures 8 and 9 .

sion of surface gp63-like proteins and trypanosomatid adhesion is suggestive of a potential role in cell adhesion (Table II). Curiously, the treatment of the wild strain of $C$. deanei with PLC reduced the exposition of surface gp63 to similar levels to those found in the untreated cured strain. Additionally, the PLC-treated wild strain and the untreated cured strain parasites adhered to $A$. aegypti guts at compa- 


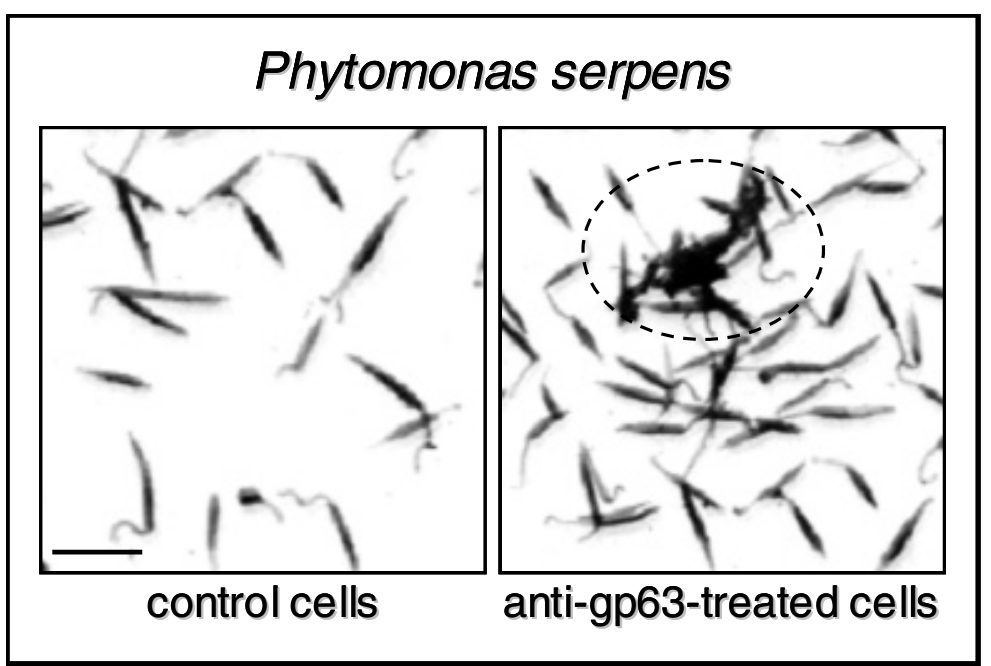

Fig. 7 - Binding of anti-gp63 antibodies (Ilg et al. 1993) to the cell surface of Phytomonas serpens promastigote cells. The living parasites were incubated in the presence of the rabbit pre-immune serum (control cells) or rabbit anti-gp63 serum (anti-gp63-treated cells) at 1:100 dilution for $1 \mathrm{~h}$. Then, cells were fixed and experimental systems were analyzed under phase contrast images. The selected area indicates the agglutination of parasites by the anti-gp63 antibody. The bar represents $10 \mu \mathrm{m}$. For experimental details see d'Avila-Levy et al. 2006a.

rable rates (C.M. d'Avila-Levy et al., unpublished data). Accordingly, the anti-gp63 antibodies prevented the binding of $P$. françai as well as $C$. deane $i$ and $C$. guilhermei to A. aegypti guts and the adhesion was also inhibited by the pre-treatment of the dissected guts with the purified gp63-like enzyme from each protozoa either proteolytically active, inactivated by the removal of ions from the active site (apoenzyme) or inactivated by denaturation (heat) (d'Avila-Levy et al. 2006a). The similar effects observed with the proteolytically active, the apoenzyme and the heat-inactivated metalloproteases suggest that the peptide sequence recognized by the $A$. aegypti gut receptor does not depend on the tertiary conformation of the gp63-like molecule. Moreover, these data suggest the saturation of insect gut cell receptors by the gp63-like polypeptide. In this sense, it was identified that a $50 \mathrm{kDa}$ protein on the A. aegypti gut extract is the receptor for the gp63-like molecules (d'Avila-Levy et al. 2006a). Representative schemes of the approaches employed for the demonstration of the proposed role of gp63-like cell surface molecules on the interac- tion of lower trypanosomatids with the invertebrate hosts were summarized in figures 8 and 9 .

The interaction of $P$. serpens with the salivary glands of Oncopeltus fasciatus was already analyzed. O. fasciatus is the natural host of several monoxenous trypanosomatids, which are found in its intestinal tract (Romeiro et al. 2000), while Phytomonas elmassiani invades the salivary glands of this bug (McGhee and Hanson 1964). Infection of the hemolymph by $P$. elmassiani is occasional and occurs only when the parasite is moving towards the salivary glands (McGhee and Hanson 1964). In addition, $P$. serpens adheres ex vivo to the salivary gland of $O$. fasciatus (F.A. Dias, unpublished data, Santos et al. 2006). The pre-treatment of the parasites with anti-gp63 antibodies reduced their adhesion to explanted salivary glands (Table II). The search for a receptor for gp63 in the salivary glands of $O$. fasciatus revealed the presence of a protein of $50 \mathrm{kDa}$ (d'Avila-Levy et al. 2006b). The identification of receptors responsible to parasite attachment to the insect is of interest since proteinaceous epitopes are potential universal disease transmis- 


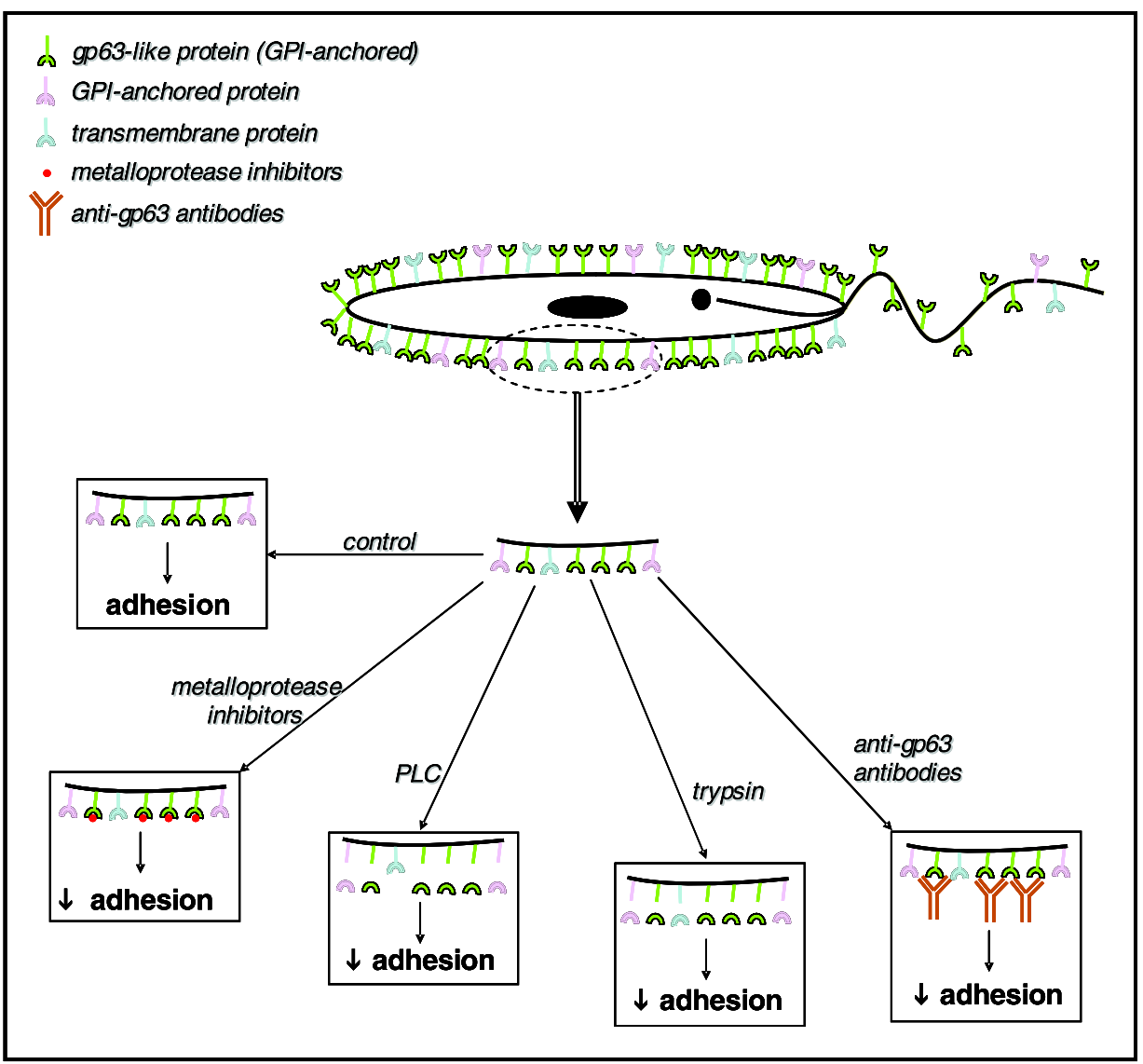

Fig. 8 - Different approaches employed for the demonstration of a proposed role performed by the gp63-like cell surface molecules on the interaction of lower trypanosomatids with the invertebrate host. The schematic representation shows a trypanosomatid cell expressing at the surface gp63-like molecules and other glycosylphosphatidylinositol (GPI)-anchored or transmembrane proteins. The adhesion rate to the insect epithelium in vitro is evaluated in untreated (control) or parasites previously treated with metalloprotease inhibitors, phospholipase C (PLC), trypsin or anti-gp63 antibodies. These treatments led to reduced levels of adhesion ( $\downarrow$ adhesion), due to removal or inactivation of gp63-like proteins from the cell surface.

sion blocking targets. The isolation and sequencing of these cellular receptors is an open field.

\section{CONCLUSIONS}

gp63 homologues are ubiquitously present on the cell surface and secreted by flagellates of the Trypanosomatidae family. It can be speculated that gp63 is subjected to the selective pressures of similar environments (invertebrate host) and it is expected to be structurally and functionally conserved in distinct trypanosomatids. In this sense, research on gp63 from lower trypanosomatids should now focus either on the extension of these data to other lower trypanosomatids or on the search for specific functions of these molecules. Taken together, these studies do not implicate the gp63-like molecules as the only adhesive molecule of lower trypanosomatids to the insect tissues, nor does it indicate the only biological role of this parasite surface molecule, but it suggests one of the important biological roles of the gp63-like molecules in the interaction of trypanosomatids with the insect host. The concerted action of other surface molecules of the parasite to stabilize the gp63-like protease activity in the insect 


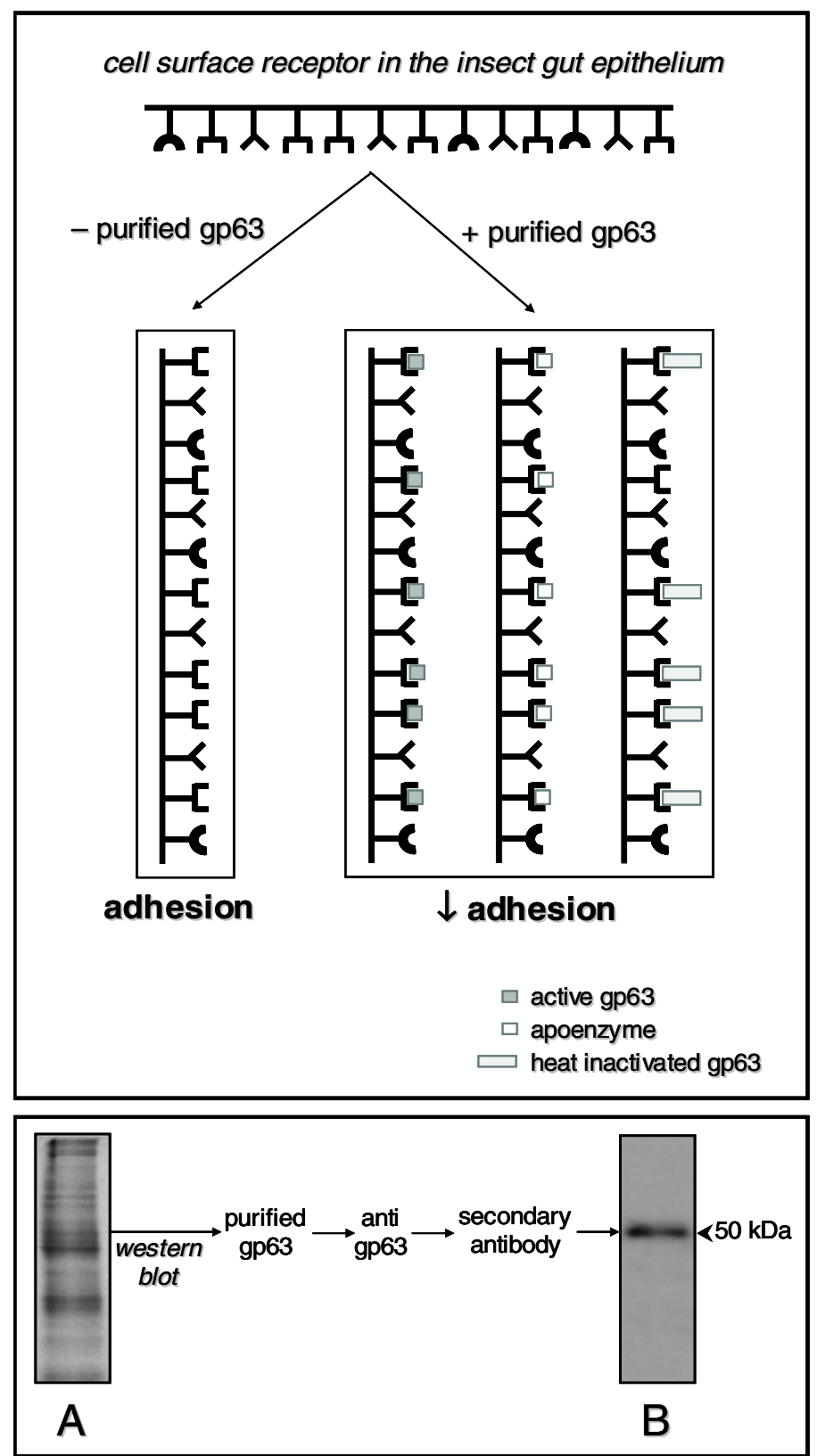

Fig. 9 - Different approaches employed for the demonstration of a proposed role performed by the gp63-like cell surface molecules on the interaction of lower trypanosomatids with the invertebrate gut epithelial cells. Schematic representation of the inhibition of trypanosomatid adhesion by purified gp63-like proteins (native, inactivated by heat or by removal of ions - apoenzyme), which suggests the saturation of insect gut receptors. The methodology employed for the detection of an insect gut receptor for gp63 is shown in the lower part of the figure. The insect gut protein extract was separated in 10\% SDS-PAGE (A), electrophoretically transferred to a nitrocellulose membrane and incubated sequentially with purified gp63-like protease, anti-gp63 antibody (Ilg et al. 1993) and peroxidase-conjugated secondary antibody. The reactive polypeptide was visualized by chemiluminescence followed by exposure to X-ray films (B). For experimental details see d'Avila-Levy et al. 2006a. 
is very possible. The generation of metalloprotease knockout mutants of these trypanosomatids is an important direction to be pursued. Finally, the ability of lower trypanosomatids to express homologues of Leishmania virulence factors confirms their relevance as a model for the biochemical studies among the Trypanosomatidae family.

\section{ACKNOWLEDGMENTS}

The authors wish to thank Ms. Iêda C.M. de Castro e Silva, Geralda R. Almeida, Bianca A. Silva, Camila G.R. Elias, Fernanda M. Pereira, Ana C. Nogueira de Melo, Fernanda M. Araújo, Fernanda A. Marinho, Lívia O. Santos, Filipe P. Matteoli and Celina M. Abreu for their technical assistance, Elise A. Hayashi for the assistance with FACS, Juliana L. Martins for the support with immunofluorescence microscopy and Felipe A. Dias and Dr. Elvira M.B. Saraiva for the help with the insect-trypanosomatid interaction experiments. The authors are grateful to Dr. Alane B. Vermelho, Ângela H.C.S. Lopes and Dr. Rosangela M.A. Soares (Instituto de Microbiologia Prof. Paulo de Góes, Universidade Federal do Rio de Janeiro, Brazil) for many helpful suggestions, Dr. Kwang-Poo Chang (University of Health Sciences, Chicago Medical School, USA) and Peter Overath (Max-Planck-Institut für Biologie, Abteilung Membranbiochemie, Germany) for kindly providing the valuable anti-gp63 antibodies, Dr. Michael A.J. Ferguson and Dr. Maria Lucia S. Guther (University of Dundee, United Kingdom) for supplying the anti-CRD antibody, Dr. Maria Cristina M. Motta (Instituto de Biofísica Carlos Chagas Filho, Universidade Federal do Rio de Janeiro, Brazil) for providing the cured and wild strains used in all works published by our group, Laboratório de Fisiologia e Controle de Vetores (Departamento de Entomologia, Instituto Oswaldo Cruz, Rio de Janeiro, Brazil) for kindly providing Aedes aegypti, and Dr. Patrícia Azambuja (Instituto Oswaldo Cruz, Rio de Janeiro, Brazil) for providing Oncopeltus fasciatus. This study was supported by the Brazilian agencies: MCT/CNPq (Conselho Nacional de
Desenvolvimento Científico e Tecnológico), CEPG/ UFRJ (Conselho de Ensino para Graduados e Pesquisas), FAPERJ (Fundação Carlos Chagas Filho de Amparo à Pesquisa do Estado do Rio de Janeiro), FUJB (Fundação Universitária José Bonifácio) and CAPES (Coordenação de Aperfeiçoamento de Pessoal de Nível Superior).

\section{RESUMO}

Tripanossomatídeos de insetos e de plantas são informalmente denominados de "tripanossomatídeos inferiores". Estes microrganismos são utilizados rotineiramente como modelos para estudos de bioquímica e de biologia molecular porque são facilmente cultivados sob condições axênicas e porque possuem homólogos aos fatores de virulência encontrados nos tripanossomatídeos que são patógenos humanos clássicos. Dentre os fatores moleculares que contribuem para a virulência e patogênese de Leishmania spp. destaca-se a principal protease de superfície, também conhecida como MSP, PSP, leishmanolisina, EC 3.4.24.36 e gp63, que é a proteína de superfície mais abundante encontrada nas formas promastigotas de Leishmania. Diversas funções foram descritas para a gp63 de Leishmania no hospedeiro vertebrado. Entretanto, pouco é conhecido sobre as funções desempenhadas por essa molécula no inseto vetor. Curiosamente, a gp63 é predominantemente expressa na forma evolutiva de Leishmania encontrada no inseto, e em todos os tripanossomatídeos de insetos e plantas analisados até o presente momento. Os homólogos da gp63 presentes nos tripanossomatídeos inferiores desempenham um papel essencial na nutrição assim como na interação com as células epiteliais do inseto. Uma vez que revisões de excelente qualidade foram produzidas na última década sobre a função de proteases nos hospedeiros vertebrados, nesta revisão nós abordamos os recentes progressos sobre os aspectos bioquímicos e as prováveis funções biológicas desempenhadas pelas proteínas homólogas à gp63 nos tripanossomatídeos inferiores.

Palavras-chave: Trypanosomatidae, tripanossomatídeos inferiores, gp63, hospedeiro invertebrado, adesão, nutrição, protease. 


\section{REFERENCES}

ALMEIDA FVS, GIOVANNI-DE-Simone S, BRANQUINHA MH AND Vermelho AB. 2003. Extracellular metalloproteinase activity in Phytomonas françai. Parasitol Res 89: 320-322.

Alvar J, Cañavate C, GutiérRez-Solar B, JiméNEZ M, LAGUNA F, LÓPEZ-VÉlez R, MOLINA R AND MORENO J. 1997. Leishmania and human immunodeficiency virus coinfection: the first 10 years. Clin Microbiol Rev 10: 298-319.

Bahr V, STIERHOF YD, ILG T, DEMAR M, QUinten M AND OVERATH P. 1993. Expression of lipophosphoglican and glycoprotein 63 in promastigotes and amastigotes of Leishmania mexicana. Mol Biochem Parasitol 58: 107-122.

Bangs JD, RAnsom DM, Nimick M, Christie G AND HOOPER NM. 2001. In vitro cytocidal effects on Trypanosoma brucei and inhibition of Leishmania major GP63 by peptidomimetric metalloprotease inhibitors. Mol Biochem Parasitol 114: 111-117.

BARrett AJ. 1994. Proteolytic enzymes: serine and cysteine peptidases. Methods Enzymol 244: 1-15.

BARRETT AJ. 1995. Proteolytic enzymes: aspartic and metallopeptidases. Methods Enzymol 248: 183.

BARRETT AJ, RAWLINGS ND AND O'BRIEN EA. 2001. The MEROPS database as a protease information system. J Struct Biol 134: 95-102.

BARRetT AJ, TOlle DP AND RAWLINGS ND. 2003. Managing peptidases in the genomic era. Biol Chem 384: 873-882.

Bode W ANd Maskos K. 2003. Structural basis of the matrix metalloproteinases and their physiological inhibitors, the tissue inhibitors of metalloproteinases. Biol Chem 384: 863-872.

Bordier C, Etges RJ, WARd J, TURner MJ AND CARdoso de Almeida ML. 1986. Leishmania and Trypanosoma surface glycoproteins have a common glycophospholipid membrane anchor. Proc Natl Acad Sci USA 83: 5988-5991.

BOUVIER J, ETGEs RJ AND BORdier C. 1985. Identification and purification of membrane and soluble forms of the major surface protein of Leishmania promastigotes. J Biol Chem 260: 15504-15509.

BOUVIER J, BORdier C, VOGEL H, REICHELT R AND ETGES RJ. 1989. Characterization of the promastig- ote surface protease of Leishmania as a membranebound zinc endopeptidases. Mol Biochem Parasitol 37: 235-245.

BOUVier J, SCHNeider P, ETGES R AND Bordier C. 1990. Peptide substrate specificity of the membranebound metalloprotease of Leishmania. Biochemistry 29: 10113-10119.

Brandẽo AA, Miranda A, Degrave WM And SousA MA. 2000. The heterogeneity of choanomastigote-shaped trypanosomatids as analyzed by their kDNA minicircle size: taxonomic implications. Parasitol Res 86: 809-812.

Branquinha MH, Barreto-Bergter E, MeirelLES MNL AND Vermelho AB. 1994a. Glycolipid and protein profiles in trypanosomatids. Parasitol Res 80: 336-341.

Branquinha MH, Vermelho AB, Goldenberg S AND BONALDO MC. 1994b. Characterization of proteinases in trypanosomatids. Braz J Med Biol Res 27: 495-499.

BRANQUinha MH, VERMELHo AB, GoldEnBERG S AND BONALDO MC. 1996. Ubiquity of cysteineand metalloproteinase in a wide range of trypanosomatids. J Eukaryot Microbiol 43: 131-135.

Breganó JW, PicÃo RC, Graca VK, Menolli RA, Itow JANKeVicius S, Pinge Filho P AND JANKEVICIUS JV. 2003. Phytomonas serpens, a tomato parasite, shares antigens with Trypanosoma cruzi that are recognized by human sera and induce protective immunity in mice. FEMS Immunol Med Microbiol 39: 257-264.

Brittingham A, Morrison CJ, MCMASTER WR, MCGWire BS, Chang KP AND Mosser DM. 1995. Role of the Leishmania surface protease gp63 in complement fixation, cell adhesion, and resistance to complement-mediated lysis. J Immunol 155: 3102-3111.

BUtTon LL AND McMaster WR. 1988. Molecular cloning of the major surface antigen of Leishmania. J Exp Med 167: 724-729.

Button Ll, Russell DG, Klein HL, MedinaAcosta E, Karess R And McMaster WR. 1989. Genes encoding the major surface glycoprotein in Leishmania are tandemly linked at a single chromosomal locus and are constitutively transcribed. Mol Biochem Parasitol 32: 271-284. 
CAMARgo EP. 1999. Phytomonas and other trypanosomatid parasites of plants and fruit. Adv Parasitol 42: 29-112.

Catarino lM, Serrano MG, Cavazzana Jr M, Almeida ML, KANESHina EK, CAMPANER M, JANKEVICIUS JV, TEIXEIRA MMG AND ITOWJANKEVICIOUS S. 2001. Classification of trypanosomatids from fruits and seeds using morphological, biochemical and molecular markers revealed several genera among fruit isolates. FEMS Microbiol Lett 201: 65-72.

CAzzulo JJ, Stoka V And Turk V. 2001. The major cysteine proteinase of Trypanosoma cruzi: a valid target for chemotherapy of Chagas' disease. Curr Pharm Des 7: 1143-1156.

Chang CS And Chang KP. 1986. Monoclonal antibody affinity purification of a Leishmania membrane glycoprotein and its inhibition of leishmaniamacrophage binding. Proc Natl Acad Sci USA 83: 100-104.

Chang CS, Inserra TJ, Kink JA, Fong D AND CHANG KP. 1986. Expression and size heterogeneity of a $63 \mathrm{kDa}$ membrane glycoprotein during growth and transformation of Leishmania mexicana amazonensis. Mol Biochem Parasitol 18: 197-210.

Chang KP, Chang CS And SASSA S. 1975. Heme biosynthesis in bacterium-protozoan symbioses: enzymatic defects in host hemoflagellates and complemental role of their intracellular symbiotes. Proc Natl Acad Sci USA 72: 2979-2983.

Chaudhuri G And Chang KP. 1988. Acid protease activity of a major surface membrane glycoprotein (gp63) from Leishmania mexicana promastigotes. Mol Biochem Parasitol 27: 43-52.

Chicarro C And Alvar J. 2003. Lower trypanosomatids in HIV/AIDS patients. Ann Trop Med Parasitol 97: 75-80.

Coombs GH And Mottram JC. 1997. Parasite proteinases and amino acid metabolism: possibilities for chemotherapeutic exploitation. Parasitology 114: S61-S80.

Corradin S, RANSiJn A, Corradin G, Roggero MA, SCHMitz AA, SCHNEIDER P, MAUEL J AND VERGERES G. 1999. MARCKS-related protein (MRP) is a substrate for the Leishmania major surface protease leishmanolysin (gp63). J Biol Chem 274: 25411-25418.
Cuevas IC, Cazzulo JJ and SÁnchez DO. 2003. gp63 homolgues in Trypanosoma cruzi: surface antigens with metalloprotease activity and a possible role in host cell infection. Infect Immun 71: 57395749.

Cupolillo E, Medina-Acosta E, Noyes H, MoMEN H AND GRIMALDI JR G. 2000. A revised classification for Leishmania and Endotrypanum. Parasitol Today 16: 142-144.

Davies CR, Cooper AM, Peacock C, LANe RP AND BLACKWELL JM. 1990. Expression of LPG and GP63 by different developmental stages of Leishmania major in the sandfly Phlebotomus papatasi. Parasitology 101: 337-343.

D’ Avila-Levy CM, Nogueira de Melo AC, VerMElHo AB AND BRANQUinha MH. 2001. Differential expression of proteolytic enzymes in endosymbiont-harboring Crithidia species. FEMS Microbiol Lett 202: 73-77.

D'Avila-Levy CM, SOUZA RF, Gomes RC, VERMELHO AB AND BRANQUinHA MH. 2003. A metalloproteinase extracellularly released by Crithidia deanei. Can J Microbiol 49: 625-632.

D'Avila-LeVy CM, Araújo FM, Vermelho AB, Branquinha MH, Alviano CS, SoARes RMA AND SANTOS ALS. 2004. Distribution of glycoproteins recognized by different lectins in seven choanomastigote-shaped trypanosomatids: taxonomic implications. FEMS Microbiol Lett 231: 171-176.

D'Avila-Levy CM, Araújo FM, Vermelho AB, SoARES RMA, SANTOS ALS AND BRANQUinha MH. 2005a. Proteolytic expression in Blastocrithidia culicis: influence of the endosymbiont and similarities with virulence factors of pathogenic trypanosomatids. Parasitology 130: 413-420.

D'AVIla-LeVy CM, Silva BA, HAYAShi EA, VERMELHO AB, Alviano CS, SARAIVA EM, BRANQUINHA MH AND SANTOS ALS. 2005b. Influence of the endosymbiont of Blastocrithidia culicis and Crithidia deanei on the glycoconjugate expression and on Aedes aegypti interaction. FEMS Microbiol Lett 252: 279-286.

D’ Avila-Levy CM, Dias FA, Nogueira de Melo AC, Martins JL, Lopes AHCS, Santos ALS, VERMELHO AB AND BRANQUiNHA MH. 2006a. Insights into the role of gp63-like proteins in insect trypanosomatids. FEMS Microbiol Lett 254: 149156. 
D'Avila-Levy CM, SAntos LO, Marinho FA, Dias FA, LOPES AHCS, SANTOS ALS AND BRANQUinha MH. 2006b. Gp63-like molecules in Phytomonas serpens: possible role on the insect interaction. Curr Microbiol 52: 439-444.

DEANE MP AND JANSEN AM. 1988. From a mono to a digenetic life-cycle: how was the jump for flagellates of the family Trypanosomatidae? Mem Inst Oswaldo Cruz 83: 273-275.

DE SouzA W. 1995. Structural organization of the cell surface of pathogenic protozoa. Micron 26: 405430.

De Souza W And MotTa MCM. 1999. Endosymbiosis in protozoa of the Trypanosomatidae family. FEMS Microbiol Lett 173: 1-8.

Dedet JP, Roche B, Pratlong F, Cales-Quist D, JouAnnelle J, Benichou JC AND Huerre M. 1995. Diffuse cutaneous infection caused by a presumed monoxenous trypanosomatid in a patient infected with HIV. Trans R Soc Trop Med Hyg 89: 644-646.

Descoteaux A And Turco SJ. 1999. Glycoconjugates in Leishmania infectivity. Biochim Biophys Acta 1455: 341-352.

Dollet M. 1984. Plant diseases caused by flagellate protozoa (Phytomonas). Annu Rev Phytopathol 22: $115-132$.

EBbert MA, Burkholder JJ AND MARlowe JL. 2001. Trypanosomatid prevalence and host habit choice in woodland Drosophila. J Invertebr Pathol 77: $27-32$.

Elias CGR, Pereira FM, Silva BA, Alviano CS, SOARES RMA AND SANTOS ALS. 2006. Leishmanolysin (gp63 metallopeptidase)-like activity extracellularly released by Herpetomonas samuelpessoai. Parasitology 132: 37-47.

ETGES R. 1992. Identification of a surface metalloproteinase on 13 species of Leishmania isolated from humans, Crithidia fasciculata, and Herpetomonas samuelpessoai. Acta Trop 50: 205-217.

Etges RJ, Bouvier J AND Bordier C. 1986. The major surface protein of Leishmania promastigotes is a protease. J Biol Chem 261: 9099-9101.

FAMPA P, CORRÊA-DA-SILVA MS, LIMA DC, OLIVEIRA SMP, MOTTA MCM AND SARAIVA EMB. 2003. Interaction of insect trypanosomatids with mosquitoes, and fly and the respective insect cell lines. Int J Parasitol 33: 1019-1026.

FAMPA P, MOTTA MCM, BARRETO-DE-SOUZA V, Bou-HABIB DC AND SARAIVA BEM. 2004. HIV1 infection and the HIV-1 transactivator TAT protein increase Blastocrithidia culicis survival in macrophages. XX Annual Meeting of the Brazilian Society of Protozoology, $165 \mathrm{p}$.

FONG D AND CHANG KP. 1982. Surface antigenic change during differentiation of a parasite protozoan, Leishmania mexicana: identification by monoclonal antibodies. Proc Natl Acad Sci USA 79: 7366-7370.

Garcia Mr, Graham S, Harris RA, Beverley SM AND KAYNE PM. 1997. Epitope cleavage by Leishmania endopeptidases(s) limits the efficiency of the exogenous pathway of major histocompatibility complex class I-associated antigen presentation. Eur J Immunol 27: 1005-1013.

GRIMM F, JENNi L, Bouvier J, ETGES RJ AND BoRDIER C. 1987. The promastigote surface protease of Leishmania donovani infantum in the midgut of Phlebhotomus perniciosus. Acta Trop 44: 375-377.

GUBLER DJ. 2004. The changing epidemiology of yellow fever and dengue, 1900 to 2003: full circle? Comp Immunol Microbiol Infect Dis 27: 319-330.

Hajmová M, Chang KP, Kolli B AND Volf P. 2004. Down-regulation of gp63 in Leishmania amazonensis reduces its early development in Lutzomyia longipalpis. Microb Infect 6: 646-649.

HERWALDT BL. 1999. Leishmaniasis. Lancet 354: 1191-1199.

Hey AS, Theander TG, HViId L, Hazrati SM, Kemp M AND Kharazmi A. 1994. The major surface glycoprotein (gp63) from Leishmania major and Leishmania donovani cleaves CD4 molecules on human T cells. J Immunol 152: 4542-4548.

Hughes AL And PiontKivska H. 2003. Molecular phylogenetics of Trypanosomatidae: contrasting results from $18 \mathrm{~S}$ rRNA and protein phylogenies. Kinetoplastid Biol Dis 2: 1-10.

Ilg T, Harbecke D AND Overath P. 1993. The lysosomal gp63-related protein in Leishmania mexicana amastigotes is a soluble metalloproteinase with an acidic pH optimum. FEBS Lett 327: 103-107.

Ilgoutz SC AND MCCONVILle MJ. 2001. Function and assembly of the Leishmania surface coat. Int $\mathbf{J}$ Parasitol 31: 899-908. 
InVERso JA, Medina-Acosta E, O'Connor J, Russell DG AND CRoss GA. 1993. Crithida fasciculata contains a transcribed leishmanial surface peptidase (gp63) gene homologue. Mol Biochem Parasitol 57: 47-54.

JAFFE CL AND DWYER DM. 2003. Extracellular release of the surface metalloprotease, gp63, from Leishmania and insect trypanosomatids. Parasitol Res 91: 229-237.

JANSEN AM, CARREIRA JC AND DEANE MP. 1988. Infection of a mammal by monogenetic insect trypanosomatids (Kinetoplastida, Trypanosomatidae). Mem Inst Oswaldo Cruz 83: 271-272.

JimÉNEZ MI, LÓPEZ-VÉlEZ R, MOLINA R, CAÑAVATE C AND Alvar J. 1996. HIV co-infection with a currently non-pathogenic flagellate. Lancet 347: 264-265.

Joshi PB, Kelly BL, Kamhawi S, Sacks DL and MCMASTER WR. 2002. Targeted gene deletion in Leishmania major identifies leishmanolysin (GP63) as a virulence factor. Mol Biochem Parasitol 120: $33-40$.

LACOUNT DJ, GRUSZYNSKI AE, GRANDGNETT PM, BANGS JD AND DONELSON JE. 2003. Expression and function of the Trypanosoma brucei major surface protease (GP63) genes. J Biol Chem 278: 24658-24664.

LeCAille F, Kaleta J And BRÖMme D. 2002. Human and parasitic papain-like cysteine proteases: their role in physiology and pathology and recent developments in inhibitors design. Chem Rev 102: 4459-4488.

LeMosy EK, Hong CC And Hashimoto C. 1999. Signal transduction by a protease cascade. Trends Cell Biol 9: 102-107.

LOPES JD, CAULADA Z, BARBIERI CL AND CAMARGO EP. 1981. Cross-reactivity between Trypanosoma cruzi and insect trypanosomatids as a basis for the diagnosis of Chagas' disease. Am J Trop Med Hyg 30: 1183-1188.

Macdonald MH, Morrison CJ And MCMaster WR. 1995. Analysis of the active site and activation mechanism of the Leishmania surface metalloproteinase GP63. Biochim Biophys Acta 1253: 199-207.
MATLASHEWSKI G. 2001. Leishmania infection and virulence. Med Microbiol Immunol 190: 37-42.

Matta MA, Aleksitch V, Angluster J, Alviano CS, De Souza W, Andrade AF and Esteves MJ. 1995. Occurrence of $N$-acetyl- and $N$-O-diacetyl-neuraminic acid derivatives in wild and mutant Crithidia fasciculata. Parasitol Res 81: 426-433.

McGhee RB And Cosgrove WB. 1980. Biology and physiology of the lower Trypanosomatidae. Microbiol Rev 44: 140-173.

MCGHeE RB AND HANSON WL. 1964. Comparison of the life cycle of Leptomonas oncopelti and Phytomonas elmasiani. J Protozool 11: 555-562.

MCGwire BS, O'CONnell WA, Chang KP AND ENGMAN DM. 2002. Extracellular release of the glycosylphosphatidylinositol (GPI)-linked Leishmania surface metalloprotease, gp63, is independent of GPI phospholipolysis. J Biol Chem 277: 8802-8809.

MCGWIRE BS, ChANG KP AND ENGEMAN DM. 2003. Migration through the extracellular matrix by the parasitic protozoan Leishmania is enhanced by surface metalloprotease gp63. Infect Immun 71: 1008-1010.

MCKerRow JH. 1999. Development of cysteine protease inhibitors as chemoterapy for parasitic diseases: insights on safety, target validation, and mechanisms of action. Int J Parasitol 29: 833-837.

McKerrow JH, Sun E, Rosenthal PJ And BouVIER J. 1993. The proteases and pathogenicity of parasitic protozoa. Annu Rev Microbiol 47: 821853.

Medina-Acosta E, Karess RE, Schwarz H And RUSSELL DG. 1989. The promastigote surface protease (gp63) of Leishmania is expressed but differentially processed and localized in the amastigote stage. Mol Biochem Parasitol 37: 263-274.

Medina-Acosta E, Karess RE And Russell DG. 1993. Structurally distinct genes for the surface protease of Leishmania mexicana are developmentally regulated. Mol Biochem Parasitol 57: 31-46.

MiYoshi S AND SHInOdA S. 2000. Microbial metalloproteases and pathogenesis. Microb Infect 2: 91-98.

Momen H. 2001. Some current problems in the systematics of trypanosomatids. Int J Parasitol 31: 640642. 
Mosser D AND Edelson PJ. 1987. The third component of complement $(\mathrm{C} 3)$ is responsible for the intracellular survival of Leishmania major. Nature 327: 329-331.

NADEL JA. 1992. Membrane bound peptidases: endocrine, paracrine, and autocrine effects. Am J Resp Cell Mol Biol 7: 469-470.

Nogueira de Melo AC, Giovanni-De-Simmone S, BRANQUINHA MH AND VERMELHO AB. 2001. Crithidia guilhermei: purification and partial characterization of a $62-\mathrm{kDa}$ extracellular metalloproteinase. Exp Parasitol 97: 1-8.

Nogueira de Melo AC, D'Avila-Levy CM, BRANQUinha MH AND Vermelho AB. 2002. Crithidia guilhermei: gelatin- and hemoglobin-degrading extracelular metalloproteinases. Exp Parasitol 102: 150-156.

Nogueira de Melo AC, D'Avila-Levy CM, Dias FA, Armada Jla, Silva HD, Lopes AHCS, SANTOS ALS, BRANQUinha MH AND VermeLHO AB. 2006. Peptidases and gp63-like proteins in Herpetomonas megaseliae: possible involvement in the adhesion to the invertebrate host. Int J Parasitol 36: 415-422.

NorTH MJ. 1982. Comparative biochemistry of the proteinases of eukaryotic microorganisms. Microbiol Rev 46: 308-340.

PODLIPAEV S. 2000. Insect trypanosomatids: the need to know more. Mem Inst Oswaldo Cruz 95: $517-$ 522.

PodlipaEV S. 2001. The more insect trypanosomatids under study-the more diverse Trypanosomatidae appears. Int J Parasitol 31: 648-652.

Podlipaev S, Frolov AO, and Kolesnikov AA. 1990. Proteomonas inconstans n.gen., n.sp. (Kinetplastida: Trypanosomatidae) - a parasite of the bug Calocoris sexguttatus (Hemiptera: Miridae). Parasitologia 24: 339-345.

Rao MB, Tanksale AM, Ghatge MS and DeshPANDE VV. 1998. Molecular and biotechnological aspects of microbial proteases. Microbiol Mol Biol Rev 62: 597-635.

RAWLINGS ND AND BARRETT AJ. 2000. MEROPS: the peptidase database. Nucleic Acids Res 28: $323-$ 325 .
RAWLINGS ND, O'BRIEN E AND BARRETT AJ. 2002. MEROPS: the protease database. Nucleic Acids Res 30: 343-346.

RAWlings ND, Tolle DP AND BARReTt AJ. 2004a. MEROPS: the peptidase database. Nucleic Acids Res 32: D160-D164.

RAWlings ND, TOlLE DP AND BARRETT AJ. 2004b. Evolutionary families of peptidase inhibitors. Biochem J 378: 705-716.

Romeiro A, Solé-Cava AM, Sousa MA, De SouZA W AND ATtias M. 2000. Ultrastructural and biochemical characterization of promastigotes and cystics forms of Leptomonas wallacei $\mathrm{n}$.sp. isolated from the intestine of its natural hosts Oncopeltus fasciatus (Hemiptera: Lygaeidae). J Eukaryot Microbiol 47: 208-220.

Roose JP AND VAN Noorden CJF. 1995. Synthetic protease inhibitors: promising compounds to arrest pathobiologic processes. J Lab Clin Med 125: 433441.

Russell DG, Talamas-Rohana $P$ and ZeleCHOWSKI J. 1989. Antibodies raised against synthetic peptides from the Arg-Gly-Asp-containing region of the Leishmania surface protein gp63 crossreact with human $\mathrm{C} 3$ and interfere with gp63-mediated binding to macrophages. Infect Immun 57: 630-632.

SAJID M AND MCKerrow JH. 2002. Cysteine proteases of parasitic organisms. Mol Biochem Parasitol 120: 1-21.

Santos Als, Ferreira A, Franco VA, Alviano CS AND SOARES RMA. 1999. Characterization of proteinases in Herpetomonas anglusteri and Herpetomonas roitmani. Curr Microbiol 39: 61-64.

Santos Als, Abreu CM, Batista LM, Alviano CS AND SOARES RMA. 2001a. Cell-associated and extracellular proteinases in Blastocrithidia culicis: influence of growth conditions. Curr Microbiol 43: 100-106.

Santos Als, Batista LM, Abreu CM, Alviano CS, Angluster J And Soares RMA. 2001 b. Developmentally regulated protein expression mediated by dimethylsulfoxide in Herpetomonas samuelpessoai. Curr Microbiol 42: 111-116.

Santos ALS, Abreu CM, Alviano CS AND SOARES RMA. 2002a. Activation of the glycosyl- 
phosphatidylinositol-anchored membrane proteinases upon release from Herpetomonas samuelpessoai by phospholipase C. Curr Microbiol 45: 293-298.

Santos ALS, Rodrigues ML, Alviano CS AND SOARES RMA. 2002b. Changes of sialomolecules during the dimethylsulfoxide-induced differentiation of Herpetomonas samuelpessoai. Parasitol Res 88: 951-955.

Santos Als, Rodrigues ML, Alviano CS, ANGLUSTER J AND SOARES RMA. 2003. Herpetomonas samuelpessoai: dimethylsulfoxide-induced differentiation is influenced by proteinase expression. Curr Microbiol 46: 11-17.

Santos Als, Abreu CM, Alviano CS and SoaRES RMA 2005. Use of proteolytic enzymes as an additional tool for trypanosomatid identification. Parasitology 130: 79-88.

SAntos ALS ET AL. 2006. Phytomonas serpens: cysteine peptidase inhibitors interfere with growth, ultrastructure and host adhesion. Int J Parasitol 36: $47-56$.

SAntos DO, Bourguignon SC, CASTro HC, Silva JS, Franco LS, Hespanho LR, Soares MJ AND CÔRTE-REAL S. 2004. Infection of mouse dermal fibroblasts by the monoxenous trypanosomatid protozoa Crithidia deanei and Herpetomonas roitmani. J Eukaryot Microbiol 51: 570-574.

Schlagenhauf E, Etges E and Metcalf P. 1998. The crystal structure of the Leishmania major surface proteinase leishmanolysin (gp63). Structure 6: 1035-1046.

SCHNEIDER P AND GLASER TA. 1993. Characterization of a surface metalloprotease from Herpetomonas samuelpessoai and comparison with Leishmania major promastigote surface protease. Mol Biochem Parasitol 58: 277-282.

SCHNEIDER P, RosAT JP, BOUVIER J, LOUIS J AND BORDIER C. 1992. Leishmania major: differential regulation of the surface metalloprotease in amastigote and promastigote stages. Exp Parasitol 75: 196206.

Sedo A, Mandys V and Krepela E. 1996. Cell membrane-bound proteases: not "only" proteolysis. Physiol Res 45: 169-176.

Silva BA, Pinto MR, SoAres RMA, BARreto-
Bergter E AND SAntos ALS. 2006. Pseudallescheria boydii releases metallopeptidases capable to cleave several proteinaceous compounds. Res Microbiol 157: 425-432.

SOARES RMA, SANTOS ALS, BONALDO MC, ANDRADE AFB, Alviano CS, Angluster J AND GOLDENBERG S. 2003. Leishmania (Leishmania) amazonensis: differential expression of proteinases and cell-surface polypeptides in avirulent and virulent promastigotes. Exp Parasitol 104: 104-112.

SOTERIADOU KP, REMOUNDS MS, KATSIKAS MC, TZINIA AK, TSIKARIS V, SAKARELlos C AND Tzartos SJ. 1992. The Ser-Arg-Tyr-Asp region of the major surface glycoprotein of Leishmania mimics the Arg-Gly-Asp-Ser cell attachment region of fibronectin. J Biol Chem 267: 13980-13985.

Sousa MA And CôRTE-Real S. 1991. Postnuclear kinetoplast in choanomastigotes of Crithidia deanei Carvalho, 1973: proposal of a new genus. Rev Inst Med Trop São Paulo 33: S8.

SOUZA MCM, REIS AP, SILVA WD AND BRENER Z. 1974. Mechanism of acquired immunity induced by Leptomonas pessoai against Trypanosoma cruzi in mice. J Protozool 21: 579-583.

Souza MCM, Mizuta K AND IKemoto H. 1980. In vitro exoantigen from Herpetomonas samuelpessoai which protects mice against Trypanosoma cruzi infection. Rev Inst Med Trop São Paulo 22: 184-191.

Tetaud E, Lecuix I, Sheldrake T, BALtz T AND FAIRLAMB AH. 2002. A new expression vector for Crithidia fasciculata and Leishmania. Mol Biochem Parasitol 120: 195-204.

TZINIA AK AND Soteriadou KP. 1991. Substratedependent $\mathrm{pH}$ optima of gp63 purified from seven strains of Leishmania. Mol Biochem Parasitol 47: 83-90.

VAINSTEIN MH AND RoITMAN I. 1986. Cultivation of Phytomonas françai associated with poor development of root system of cassava. J Protozool 33: 511-513.

VAN WART HE AND BIRKEDAL-HANSEN H. 1988. The cysteine switch: a principle of regulation of metalloproteinase activity with potencial applicability to the entire matrix metalloproteinase gene family. Proc Natl Acad Sci USA 87: 5578-5582. 
Vermelho AB, Almeida FVS, Bronzato LS AND BRANQUINHA MH. 2003. Extracellular metalloproteinases in Phytomonas serpens. Can J Microbiol 49: 221-224.

VICKERMAN K. 1994. The evolutionary expansion of the trypanosomatid flagellates. Int J Parasitol 24: $1317-1331$.

WALLACE FG. 1966. The trypanosomatid parasites of insects and arachnids. Exp Parasitol 18: 124-193.

Wallace FG, CAmargo EP, McGhee RB And ROITMAN I. 1983. Guidelines for the description of new species of lower trypanosomatids. J Protozool 30: 308-313.

Weinman D AND CHEONG WH. 1978. Herpetomonas, with bacterium-like inclusions, in Malaysian Aedes aegypti and Aedes albopictus. J Protozool 25: 167169.
Weise F, STIERHof YD, KuHN C, Wiese M AND OVERATH P. 2000. Distribution of GPI-anchored proteins in the protozoan parasite Leishmania, based on an improved ultrastructural description using high-pressure frozen cells. J Cell Sci 113: 45874603.

WOLF DH. 1992. Proteases as biological regulators. Experientia 48: 117-118.

Yao C, Leidal KG, Brittingham A, Tarr DE, DONELSON JE AND WILson ME. 2002. Biosynthesis of the major surface protease GP63 of Leishmania chagasi. Mol Biochem Parasitol 121: 119-28.

Yao C, Donelson JE And Wilson ME. 2003. The major surface protease (MSP or GP63) of Leishmania sp. biosynthesis, regulation of expression and function. Mol Biochem Parasitol 132: 1-16. 